\title{
Fishes in the Forested Flood Plain of the Ochlockonee River, Florida, During Flood and Drought Conditions
}

\section{By Helen M. Leitman, Melanie R. Darst, and Jeffery J. Nordhaus}

\section{U.S. GEOLOGICAL SURVEY}

Water-Resources Investigations Report 90-4202

Prepared in cooperation with the

Division of Fisheries;

Nongame Wildlife Program, Division of Wildlife;

FLORIDA GAME AND FRESH WATER FISH COMMISSION

The research described in this document was funded partly by grant N687-043

from the Florida Game and Fresh Water Fish Commission's Nongame Wildlife Program, with funds derived from the Nongame Wildlife Trust Fund. This document constitutes Nongame Wildlife Program Technical Report No. 9. 


\section{U.S. DEPARTMENT OF THE INTERIOR \\ MANUEL LUJAN, Jr., Secretary}

\section{U.S. GEOLOGICAL SURVEY \\ Dallas L. Peck, Director}

For additional information write to:

District Chief

U.S. Geological Survey

Suite 3015

227 North Bronough Street

Tallahassee, Florida 32301
Copies of this report can be purchased from:

U.S. Geological Survey

Books and Open-File Reports

Federal Center, Building 810

Box 25425

Denver, Colorado 80225 


\section{CONTENTS}

\section{Conversion factors $\mathbf{V}$}

List of common names used and scientific equivalents VI

Abstract 1

Introduction 1

Purpose and scope 2

Acknowledgments 2

Geographic setting 2

Ochlockonee River drainage basin 2

Ochlockonee River and flood plain 4

Study sites 4

Methods of investigation 9

Hydrologic methods 9

Vegetation sampling methods 9

Fish sampling methods 9

Hydrology of river and flood plain $\mathbf{1 0}$

Vegetation in forested flood plain $\mathbf{1 3}$

Plant communities 13

Vegetative structure 13

River-flood-plain fishes 14

Fishes in flood plain during flood conditions 14

Fishes in flood plain during drought conditions $\mathbf{1 6}$

Evidence of reproduction 17

Comparisons of main channel and flood-plain species

Electrofishing collections 18

All collections combined $\mathbf{2 1}$

Importance of flood-plain hydrology to fishes $\mathbf{2 1}$

Importance of flood-plain vegetation to fishes $\mathbf{2 2}$

Summary and conclusions $\mathbf{2 3}$

Selected references $\mathbf{2 5}$

Appendix I. All fishes collected in the Ochlockonee River and flood plain by five different methods from October 1987 to August 198929

Appendix II. Fishes collected in the flood plain in spawning condition with sampling date, location, and hydrologic conditions $\mathbf{3 3}$

Appendix III. Young-of-the-year fishes collected in the flood plain with sampling date, location, and hydrologic conditions $\mathbf{3 5}$

\section{FIGURES}

1-2. Maps showing:

1. Drainage basin of the Ochlockonee River in Florida and Georgia 3

2. Location of study sites on the upper Ochlockonee River in Florida 5 
3-5. Maps and cross sections showing:

3. Approximate location and elevation of flood-plain features at the Lester site 6

4. Approximate location and elevation of flood-plain features at the Old Bainbridge Road site 7

5. Approximate location and elevation of flood-plain features at the Ochlockonee River Wildlife Management Area site 8

6-10. Graphs showing:

6. Fish sampling efforts by date and method in relation to river stage at Havana gage $\mathbf{1 1}$

7. Mean monthly river stage for 1988 and 1989 water years and long-term record (1931-89) at Havana gage 12

8. The amount of live and dead vegetative structure up to 150 centimeters above ground level in fall-winter (before flooding) and spring-summer (after flooding) 13

9. Electrofishing catch per unit effort in relation to river stage at Havana gage $\mathbf{2 0}$

10. Area available to fishes in relation to river stage at Havana gage $\mathbf{2 0}$

\section{TABLES}

1. Percentage of time flood-plain features were flooded by or connected to the river during the study and over a long period of record (1931-89) 12

2. Canopy tree species on high terraces, low terraces, and cypress-tupelo depressions $\mathbf{1 3}$

3. Fishes collected in the Ochlockonee River flood plain during flood conditions by five different methods 15

4. Fishes collected in isolated ponds of the Ochlockonee River flood plain during drought conditions by three different methods 16

5. Electrofishing catches in river, backwater, and flood-plain habitats of the Ochlockonee River 19 


\section{CONVERSION FACTORS}

All data in this report are presented in $\mathrm{SI} /$ metric units except for river stage which is presented in feet, discharge which is presented in cubic feet per second, and velocity which is presented in feet per second (to allow direct comparisons to USGS hydrologic records which are reported in inch/pound units). Units used in this report may be converted using the following conversion factors:

\begin{tabular}{rll}
\hline Multiply & By & To obtain \\
\hline millimeter $(\mathrm{mm})$ & 0.03937 & inch (in.) \\
centimeter $(\mathrm{cm})$ & 0.3937 & inch (in.) \\
meter $(\mathrm{m})$ & 3.281 & foot $(\mathrm{ft})$ \\
kilometer $(\mathrm{km})$ & 0.6214 & mile (mi) \\
square meter $\left(\mathrm{m}^{2}\right)$ & 10.76 & square foot $\left(\mathrm{ft}^{2}\right)$ \\
hectare $(\mathrm{ha})$ & 2.471 & acre \\
square kilometer $\left(\mathrm{km}{ }^{2}\right)$ & 0.3861 & square mile $\left(\mathrm{mi}^{2}\right)$ \\
$\operatorname{gram}(\mathrm{g})$ & 0.03527 & ounce avoirdupois \\
& & $($ oz avdp) \\
foot $(\mathrm{ft})$ & 1.0 & part per million $(\mathrm{ppm})$ \\
milligram per liter $(\mathrm{mg} / \mathrm{L})$ & 0.3048 & meter $(\mathrm{m})$ \\
square foot $\left(\mathrm{ft}^{2}\right)$ & 929.0 & square centimeter $\left(\mathrm{cm}^{2}\right)$ \\
cubic foot $\left(\mathrm{ft}^{3}\right)$ & 0.02832 & cubic meter $\left(\mathrm{m}^{3}\right)$ \\
foot per second $(\mathrm{ft} / \mathrm{s})$ & 0.3048 & meter per second $(\mathrm{m} / \mathrm{s})$ \\
cubic foot per second $\left(\mathrm{ft}^{3} / \mathrm{s}\right)$ & 0.02832 & cubic meter per second \\
& & $\left(\mathrm{m}^{3} / \mathrm{s}\right)$ \\
\end{tabular}

Sea Level: In this report "sea level" refers to the National Geodetic Vertical Datum of 1929 (NGVD of 1929)--a geodetic datum derived from a general adjustment of the first-order level nets of both the United States and Canada, formerly called "Sea Level Datum of 1929."

Water year: In Geological Survey reports dealing with surface-water supply, water year is the 12-month period October 1 through September 30. The water year is designated by the calendar year in which it ends and which includes 9 of the 12 months. Thus, the year ending September 30, 1990, is called the "1990 water year." 


\section{LIST OF COMMON NAMES USED AND SCIENTIFIC EQUIVALENTS}

[Nomenclature for fishes follows Robins and others (1980), unless otherwise indicated. A complete list of all scientific names of fishes in phylogenetic order by family is presented in appendix I.

\begin{tabular}{|c|c|}
\hline Common names & Scientific names \\
\hline \multicolumn{2}{|c|}{ Fishes } \\
\hline banded pygmy sunfish & Elassoma zonatum Jordan \\
\hline bannerfin shiner & Notropis leedsi Fowler \\
\hline black crappie & Pomoxis nigromaculatus (Lesueur) \\
\hline blackbanded darter & Percina nigrofasciata (Agassiz) \\
\hline blacktail shiner & Notropis venustus (Girard) \\
\hline bluegill & Lepomis macrochirus (Rafinesque) \\
\hline bluespotted sunfish & Enneacanthus gloriosus (Holbrook) \\
\hline bowfin & Amia calva Linnaeus \\
\hline brook silverside & Labidesthes sicculus (Cope) \\
\hline brown bullhead & Ictalurus nebulosus (Lesueur) \\
\hline chain pickerel & Esox niger Lesueur \\
\hline channel catfish & Ictalurus punctatus (Rafinesque) \\
\hline clear chub & Hybopsis winchelli (Girard) \\
\hline coastal shiner & Notropis petersoni Fowler \\
\hline common carp & Cyprinus carpio Linnaeus \\
\hline dollar sunfish & Lepomis marginatus (Holbrook) \\
\hline Everglades pygmy sunfish & Elassoma evergladei Jordan \\
\hline flier & Centrarchus macropterus (Lacepéde) \\
\hline Florida gar & Lepisosteus platyrhincus DeKay \\
\hline gizzard shad & Dorosoma cepedianum (Lesueur) \\
\hline golden shiner & Notemigonus crysoleucas (Mitchill) \\
\hline green sunfish & Lepomis cyanellus Rafinesque \\
\hline Gulf darter & Etheostoma swaini (Jordan) \\
\hline lake chubsucker & Erimyzon sucetta (Lacepéde) \\
\hline largemouth bass & Micropterus salmoides (Lacepéde) \\
\hline least killifish & Heterandria formosa Agassiz \\
\hline lined topminnow & Fundulus lineolatus (Agassiz) \\
\hline longnose gar & Lepisosteus osseus (Linnaeus) \\
\hline mosquitofish & Gambusia affinis (Baird and Girard) \\
\hline pirate perch & Aphredoderus sayanus (Gilliams) \\
\hline pugnose minnow & Notropis emiliae (Hay) \\
\hline redbreast sunfish & Lepomis auritus (Linnaeus) \\
\hline redear sunfish & Lepomis microlophus (Günther) \\
\hline redfin pickerel & Esox americanus americanus Gmelin \\
\hline southern brook lamprey & Ichthyomyzon gagei Hubbs and Trautman \\
\hline speckled madtom & Noturus leptacanthus Jordan \\
\hline spotted bullhead & Ictalurus serracanthus Yerger and Relyea \\
\hline spotted sucker & Minytrema melanops (Rafinesque) \\
\hline spotted sunfish & Lepomis punctatus (Valenciennes) \\
\hline Suwannee bass & Micropterus notius Bailey and Hubbs \\
\hline swamp darter & Etheostoma fusiforme (Girard) \\
\hline tadpole madtom & Noturus gyrinus (Mitchill) \\
\hline taillight shiner & Notropis maculatus (Hay) \\
\hline threadfin shad & Dorosoma petenense (Günther) \\
\hline warmouth & Lepomis gulosus (Cuvier) \\
\hline weed shiner & Notropis texanus (Girard) \\
\hline white bass & Morone chrysops (Rafinesque) \\
\hline white catfish & Ictalurus catus (Linnaeus) \\
\hline yellow bullhead & Ictalurus natalis (Lesueur) \\
\hline
\end{tabular}




\section{LIST OF COMMON NAMES USED AND SCIENTIFIC EQUIVALENTS--Continued}

[Nomenclature for plants follows Godfrey (1988), unless otherwise indicated]

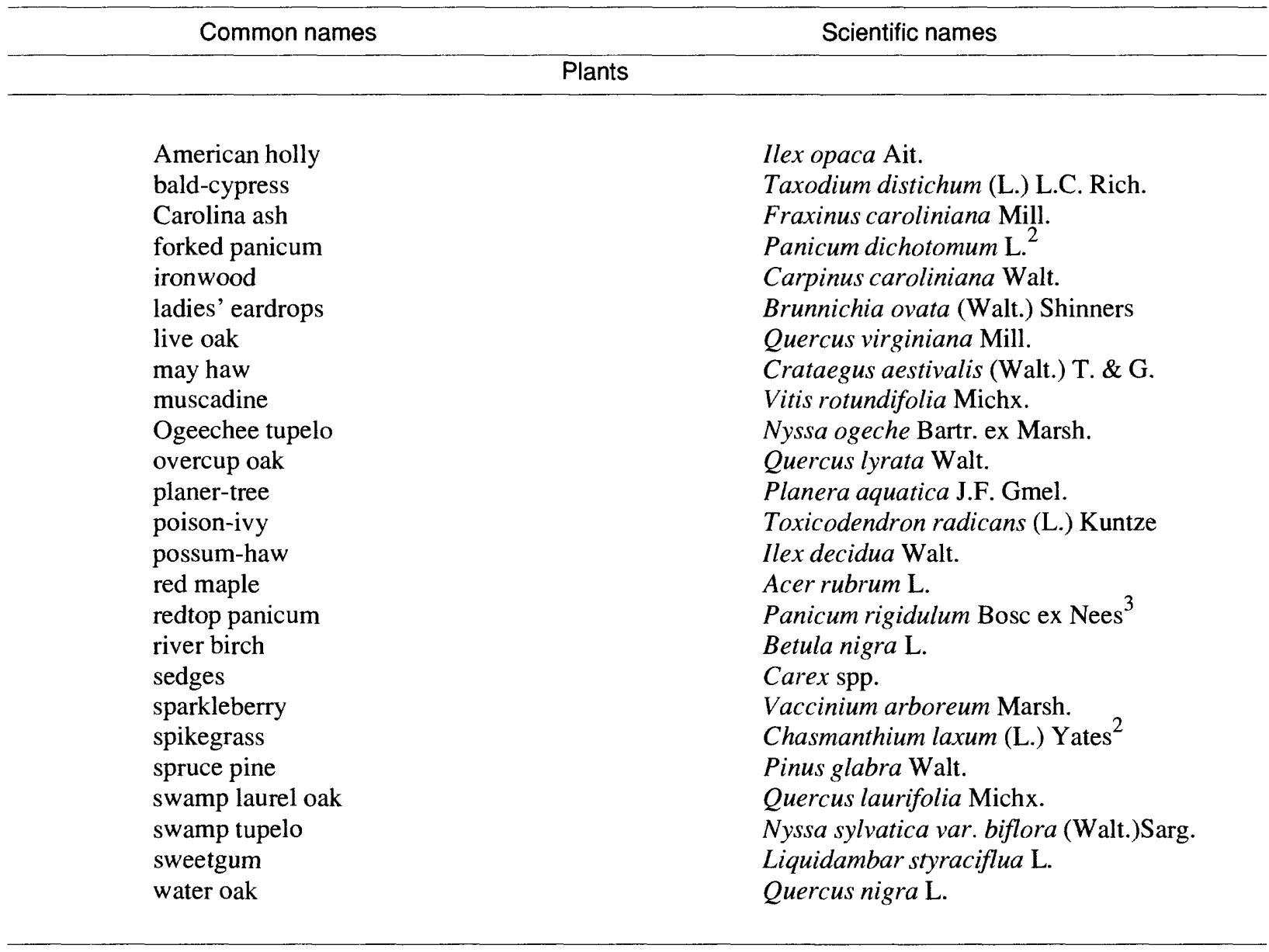

${ }^{1}$ Lee and others (1980); identified as Hybopsis amblops by Swift and others (1977).

${ }^{2}$ Godfrey and Wooten (1979)

${ }^{3}$ Clewell (1985) 


\title{
Fishes in the Forested Flood Plain of the Ochlockonee River, Florida, During Flood and Drought Conditions
}

\author{
By Helen M. Leitman, Melanie R. Darst, and Jeffery J. Nordhaus
}

\begin{abstract}
A study of hydrologic conditions, vegetation, and fishes was made in the Ochlockonee River and flood plain in northwest Florida from 1987 to 1989 . The study was conducted by the U.S. Geological Survey in cooperation with the Florida Game and Fresh Water Fish Commission to document the importance of the flood-plain environment to fishes.

A total of 8,225 fish belonging to 15 families and 48 species was collected during the study in flood-plain, backwater, and main channel habitats by five different sampling methods. During floods, three-quarters of the fish species known to occur in the main channel were collected in the flood plain. The most frequently collected species in the flood plain during floods were weed shiner (Notropis texanus), redbreast sunfish (Lepomis auritus), brown bullhead (/ctalurus nebulosus), bluegill (Lepomis macrochirus), gizzard shad (Dorosoma cepedianum), mosquitofish (Gambusia affinis), and redear sunfish (Lepomis microlophus). The study period included a drought during which flood-plain ponds were isolated from the river for 10 to 14 months. Thirteen species found in isolated flood-plain ponds had survived low dissolved-oxygen concentrations the preceding fall. Flier (Centrarchus macropterus), pirate perch (Aphredoderus sayanus), mosquitofish, and warmouth (Lepomis gulosus) were the most frequently collected drought pond species. Seven common flood-plain species that were rare or absent in the main channel apparently depend on flood-plain, backwater, and tributary habitats for their survival in this river system: flier, banded pygmy sunfish (Elassoma zonatum), bluespotted sunfish (Enneacanthus gloriosus), least killifish (Heterandria formosa), taillight shiner (Notropis maculatus), redfin pickerel (Esox americanus americanus), and brown bullhead.

The annual flood season of the Ochlockonee River typically occurs in January, February, March, and April. Summer floods are common but usually of shorter duration than winter-spring floods. Typical range in stage is 16 feet from the low to the high for the year. Alluvial flood-plain processes such as erosion and sediment deposition create topographic relief on the flood-plain surface that allows diverse habitats to develop. Riverbank levees and terraces serve as berms during low and medium river stages, separating still-water habitats in ponds and depressions from the flowing
\end{abstract}

waters of the main channel. During high river stage, all areas of the flood plain are covered with flowing water.

Tree communities were distinctly different in each topographic zone, reflecting the varied hydrologic conditions existing within the flood plain. High terraces supported a mixture of canopy species including spruce pine (Pinus glabra), sweetgum (Liquidambar styraciflua), live oak (Quercus virginiana), and water oak (Quercus nigra), and were flooded an average of 2 to 3 weeks a year from 1931 to 1989 . Low terraces, dominated by a canopy of swamp laurel oak (Quercus laurifolia), were normally flooded a total of 2 to 4 months a year. The dominant canopy species in depressions was Ogeechee tupelo (Nyssa ogeche), with bald-cypress (Taxodium distichum) the most common associate. Depressions were typically flooded by the river a total of 3 to 5 months a year, but water was often trapped in these areas long after floods receded. Live and dead vegetative structure in the flood plain, and the amount of time it was flooded, varied with topographic zone and season.

The fluctuating hydrologic conditions of the river-flood-plain system, along with the variety of alluvial features and tree communities, contribute to diversity in the fish community. During low water, flood-plain ponds support a fish community distinctly different from that of flowing waters of the main channel. During high water, flood-plain ponds mix with flood waters, and all river-flood-plain fishes gain access to diverse forest habitats.

\section{INTRODUCTION}

Forested flood plains are used by riverine fishes as a source of food and cover and as spawning and nursery grounds (Larson and others, 1981; Wharton and others, 1982; Lambou, 1990). Seasonal inundation of vegetated flood plains provides sites for egg deposition, shelter for nest building, protective cover for juvenile fishes, and food in the form of abundant macroinvertebrate prey (Wharton and others, 1981). Flood-plain ponds and backwater lakes often serve as reservoirs for fishes during periods of low water (Lambou, 1959; Mitsch and Gosselink, 1986).

Flood-plain forests along tropical rivers have been recognized as crucial to the maintenance of a viable 
community of riverine fishes (Welcomme, 1979; Goulding, 1980; Lowe-McConnell, 1987). However, studies of fish populations on seasonally inundated flood plains has been limited in temperate regions and almost nonexistent in Florida. Knowledge of riverine fish ecology in Florida is primarily based on collections in permanent stream channels. Bass (1983, p. 65) states in his discussion of Florida rivers and fishes: "Mechanisms by which fish exploit floodplains are not well known and ... studies to determine the actual degree of use of flooded woodlands would be highly desirable." Needed scientific study of flood plains as fisheries habitat is hampered by their hydrologic complexity and by practical and logistical problems in using conventional fish sampling techniques in seasonally inundated forests.

This study was undertaken to document the importance of the flood-plain environment to Ochlockonee River fishes. It was conducted by the U.S. Geological Survey, in cooperation with two divisions of the Florida Game and Fresh Water Fish Commission (FGFWFC). Much of the fish sampling and identification was conducted or assisted by the FGFWFC Division of Fisheries. The Nongame Wildlife Program of the FGFWFC Division of Wildlife provided partial financial support.

\section{Purpose and Scope}

This report relates hydrologic conditions and vegetation to fish communities in the upper Ochlockonee River flood plain in Florida. Major objectives of this report are:

1. To describe surface-water fluctuations in the various topographic zones of the forested flood plain and relate them to long-term stage record in the main channel.

2. To describe major plant community types and vegetative structure for three topographic zones of the flood plain.

3. To identify fish species that inhabit the flood plain during both flood and drought conditions and compare them to fishes of the main river channel.

4. To describe the importance of flood-plain hydrology and vegetation to fishes.

The study was limited in area to a 27-kilometer reach of the Ochlockonee River in Florida and its flood plain (fig. 1). Field work began in September 1987 and continued through August 1989.

\section{Acknowledgments}

The authors are grateful to Lt. Col. Raymond Lester for his volunteer services observing and recording water levels at a staff gage every day for 2 years. Eric A. Long, FGFWFC Division of Fisheries, assisted with reconnaissance, study design, fish sampling, and fish identification in the first year of the project. Daniel A. Dobbins and Brian R. Lubinski, FGFWFC Division of Fisheries, helped with fish sampling and identification on numerous occasions. Lothian A. Ager, FGFWFC Division of Fisheries, is appreciated for his input and support during the conception phase of the project and his review comments along the way. David G. Cook, FGFWFC Nongame Wildlife Program, reviewed interim and final reports and provided support throughout the project on grant-related matters. John A. Baker, Waterways Experiment Station, U.S. Army Corps of Engineers, generously contributed to this effort by sharing his knowledge of fish ecology and research at several stages of the project and reviewing the final document. The authors are grateful to the following additional reviewers: D. Gray Bass, Jr., FGFWFC Division of Fisheries; and Ralph W. Yerger, Professor Emeritus, Biological Sciences, Florida State University .

\section{GEOGRAPHIC SETTING}

This section describes the drainage basin, main channel, and flood plain of the Ochlockonee River. It also provides information about the location and topography of the study sites and the criteria used for selection of the sites.

\section{Ochlockonee River Drainage Basin}

The Ochlockonee River drains approximately $5,880 \mathrm{~km}^{2}$ (square kilometers) of southwestern Georgia and northwest Florida between the Apalachicola and Suwannee River basins (fig. 1). The river traverses three physiographic provinces, the Tifton Upland District in Georgia (Clark and Zisa, 1976), the Tallahassee Hills, and the Gulf Coastal Lowlands in Florida (Puri and Vernon, 1964). Its two largest tributaries, Little River and Telogia Creek, enter the river downstream of the study area. The absence of streams east of the river is punctuated by the presence of two large lake basins, Lake Jackson and Lake Iamonia. According to Cooke (1939, p. 103), their "dendritic shorelines resemble those of reservoirs formed by damming flowing streams. The shape of these lakes suggests that they were originally surface streams, which have been captured by underground drainage. ... Lake Iamonia still maintains a channel through which flood water flows from the Ochlockonee River into the lake or from the lake into the river, the direction of flow depending upon which happens to be higher." The Ochlockonee River enters Lake Iamonia when river levels in that vicinity exceed approximately 99 feet above sea level. The river has risen to that level 34 of the last 59 years, typically in one or two peak flood events of short duration. Lake Talquin, a 3,200-hectare reservoir, was created in 1929 by construction of the Jackson Bluff Hydroelectric Dam on the Ochlockonee River. River levels are artificially stabilized and velocities slowed in the Ochlockonee River just upstream of the lake. However, the study area in this 


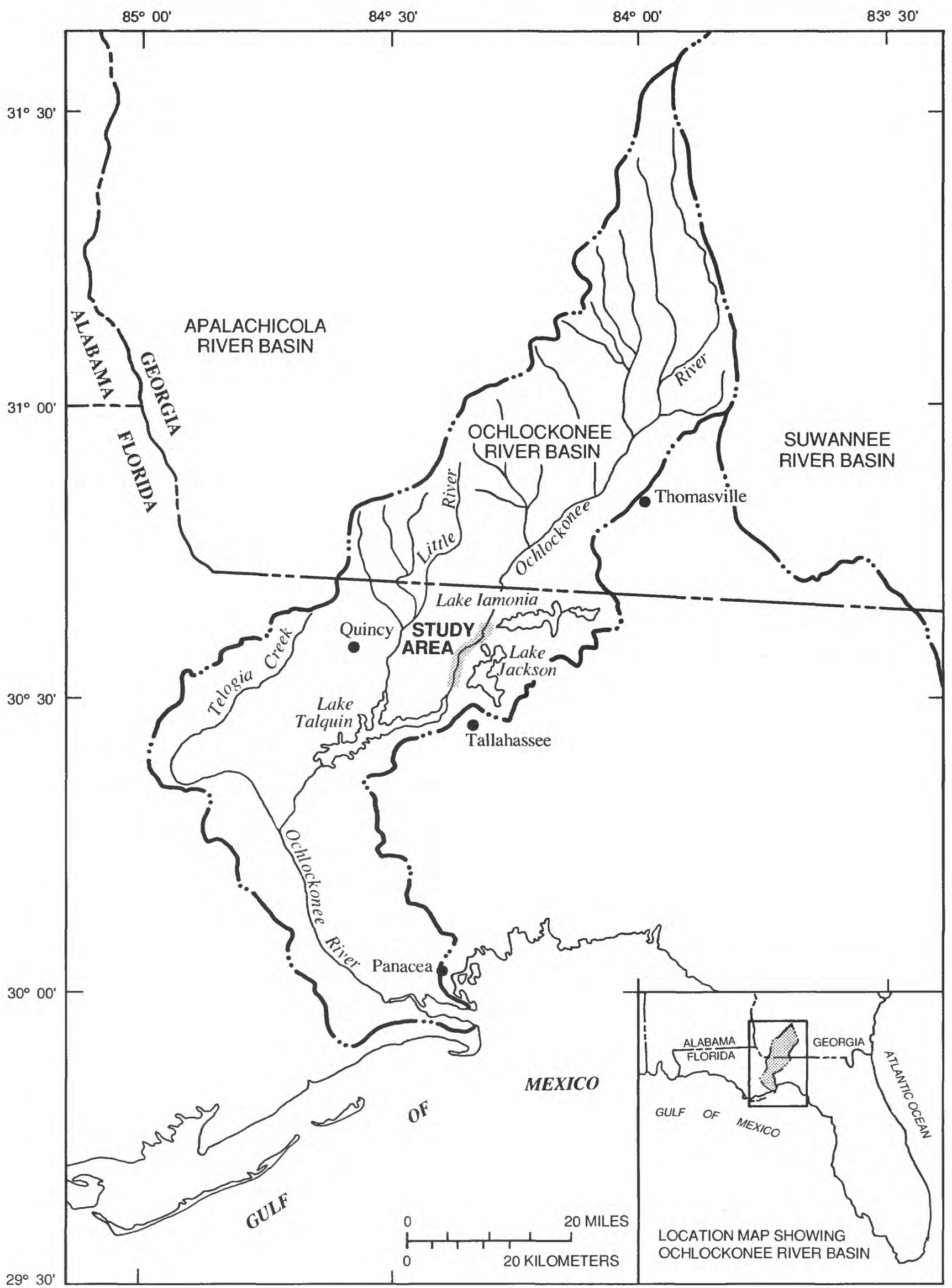

Figure 1. Drainage basin of the Ochlockonee River in Florida and Georgia. 
report is located upstream of the zone of influence of Lake Talquin.

Several point sources of pollution in the upper Ochlockonee River basin in Georgia were identified in a recent water-quality study by the Florida Department of Environmental Regulation (1987). Monitoring results indicated that domestic and industrial discharges in Georgia caused nutrient enrichment of the river in Florida. Bioassays detected toxic substances in Georgia tributaries, but toxicity was not evident downstream in Florida waters. Another pollutant from Georgia reaching the river in Florida was sediment. Erosion and sedimentation problems in the basin are probably a result of conversion of forests to cropland in southwest Georgia that has been occurring since the 1940 's, accelerated in the mid-1970's, and is expected to continue. In the mid-1980's, 40 percent of the land in southwest Georgia in the counties bordering the Ochlockonee River was under cultivation. By comparison, 8 percent of the land in Leon County and Gadsden County in Florida was cultivated (Florida Department of Environmental Regulation, 1987). A decline in fisheries due to increased sedimentation has been reported by citizens in both Florida and Georgia; however, attempts by fishery biologists in both States to document this decline have so far produced inconclusive results (Ober and Keefer, 1983; Florida Department of Environmental Regulation, 1987).

\section{Ochlockonee River and Flood Plain}

The Ochlockonee River ranks sixth in magnitude with respect to average discharge among the rivers of Florida (Heath and Conover, 1981). Mean annual flow is $1,030 \mathrm{ft}^{3} / \mathrm{s}$ (cubic feet per second) and the mean annual flood is 7,070 $\mathrm{ft}^{3} / \mathrm{s}$ at the gage on the Ochlockonee River near Havana for 1931-89 (U.S. Geological Survey, 1931-89). Range in stage at the Havana gage is 16 feet from median lowest to median highest stages for the 59-year period of record. The annual flood season typically occurs in January, February, March and April of each year. Low flow generally occurs in October and November. Flood patterns vary greatly from year to year and may not conform to these seasonal trends in any given year.

The river channel at low water averages 30 to 40 meters in width with a maximum depth ranging from 0.5 to 1.0 meter usually near steep cut banks of outside bends. Fallen trees are common in the main river channel, and leaning trees overhang the banks. Inside bends (point bars) are broad sand beaches sloping gradually into the channel. Downstream ends of these sandbars often partly enclose a backwater with no current and a soft mud bottom. During floods, depths in the main channel and in low areas in the flood plain can reach 5 meters or more.

The forested flood plain of the Ochlockonee River in Florida ranks eighth in size relative to other river flood plains in Florida. It is 51 kilometers long and encompasses approximately $124 \mathrm{~km}^{2}$ in Florida (Wharton and others,
1977). The Ochlockonee River flood plain in the vicinity of the study area averages 600 meters in width and has many topographic features characteristic of alluvial rivers (Leopold and others, 1964). Natural levees border the river channel with the remaining flood plain consisting of a mosaic of ridges, terraces, depressions, sloughs, oxbow lakes, and ponds of various sizes. Levees, ridges, and terraces are used in this report to refer to areas from which floodwaters drain shortly after floods recede. Depressions hold water after floods recede and after heavy local rains, but are normally dry part of each year during periods of low water. Sloughs serve as passageways through riverbank levees for floodwaters to enter and exit the flood plain, and they contain isolated pools of water during dry periods. An oxbow lake is formed from its associated river when the parent river changes course. At first the oxbow looks much like the main river channel and may still be connected to the river, but sediment deposition slowly fills in the oxbow over time and it eventually becomes isolated from the river except during floods (Bedinger, 1981). The Ochlockonee flood plain has recently formed oxbow lakes as well as remnant oxbow ponds of a variety of sizes.

Erosion and sediment deposition create topographic relief on the surface of alluvial flood plains that allows diverse habitats to develop (Mitsch and Gosselink, 1986). A 2.5-meter rise from the floor of a depression to the top of a high terrace 5 meters away is not uncommon on the Ochlockonee River flood plain. Depressions are vegetated with Ogeechee tupelo and bald-cypress trees with a very sparse shrub and ground cover layer. Terraces and ridges support a variety of bottomland tree species including swamp laurel oak, spruce pine, sweet gum, and red maple.

\section{Study Sites}

The locations of three flood-plain study sites and seven secondary sites on the upper Ochlockonee River, Fla., are shown in figure 2. Five secondary sites were located in the main channel along steep, brushy banks. One secondary site was located in an oxbow lake and another in an open backwater; both were just off the main channel and connected to it at low water. Selection criteria for flood-plain study sites were boat access into the flood plain at medium and high flood levels, nearby benchmarks with known vertical elevations, four distinct topographic zones at each plot (high terraces, low terraces, depressions, and ponds), and relatively undisturbed vegetation. History of timber harvesting was unknown; however, all three sites had the general aspect of relatively mature forests.

The Lester site was located on the Gadsden County side of the river bordering a slough approximately 200 meters upstream from the point where it enters the river (fig. 3). The site was bounded on the west by a high terrace that dropped steeply to a low terrace bordering the slough. The slough received runoff from adjacent uplands by way of a small intermittent tributary. Velocities in the slough were 


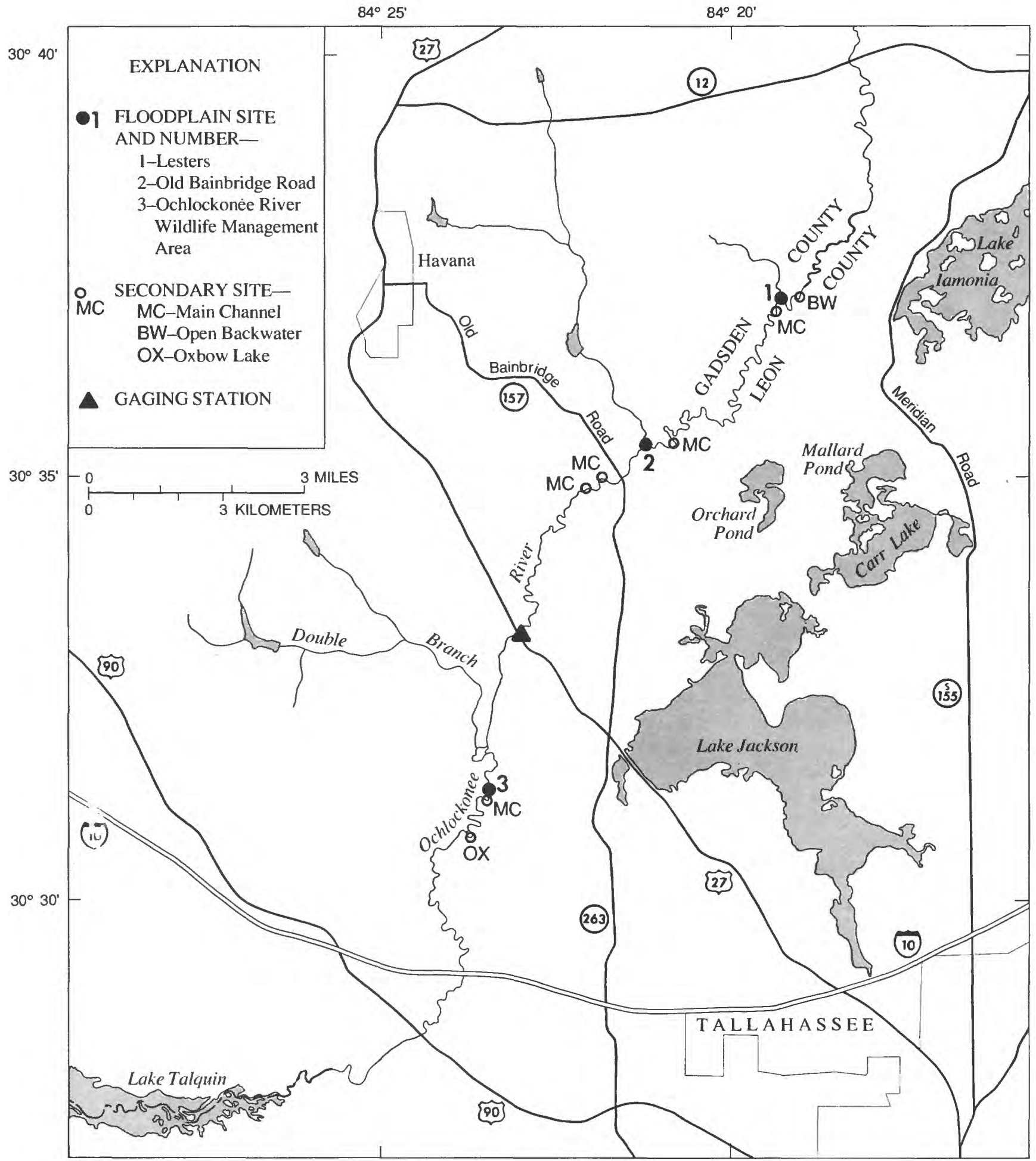

Figure 2. Location of study sites on the upper Ochlockonee River in Florida. 


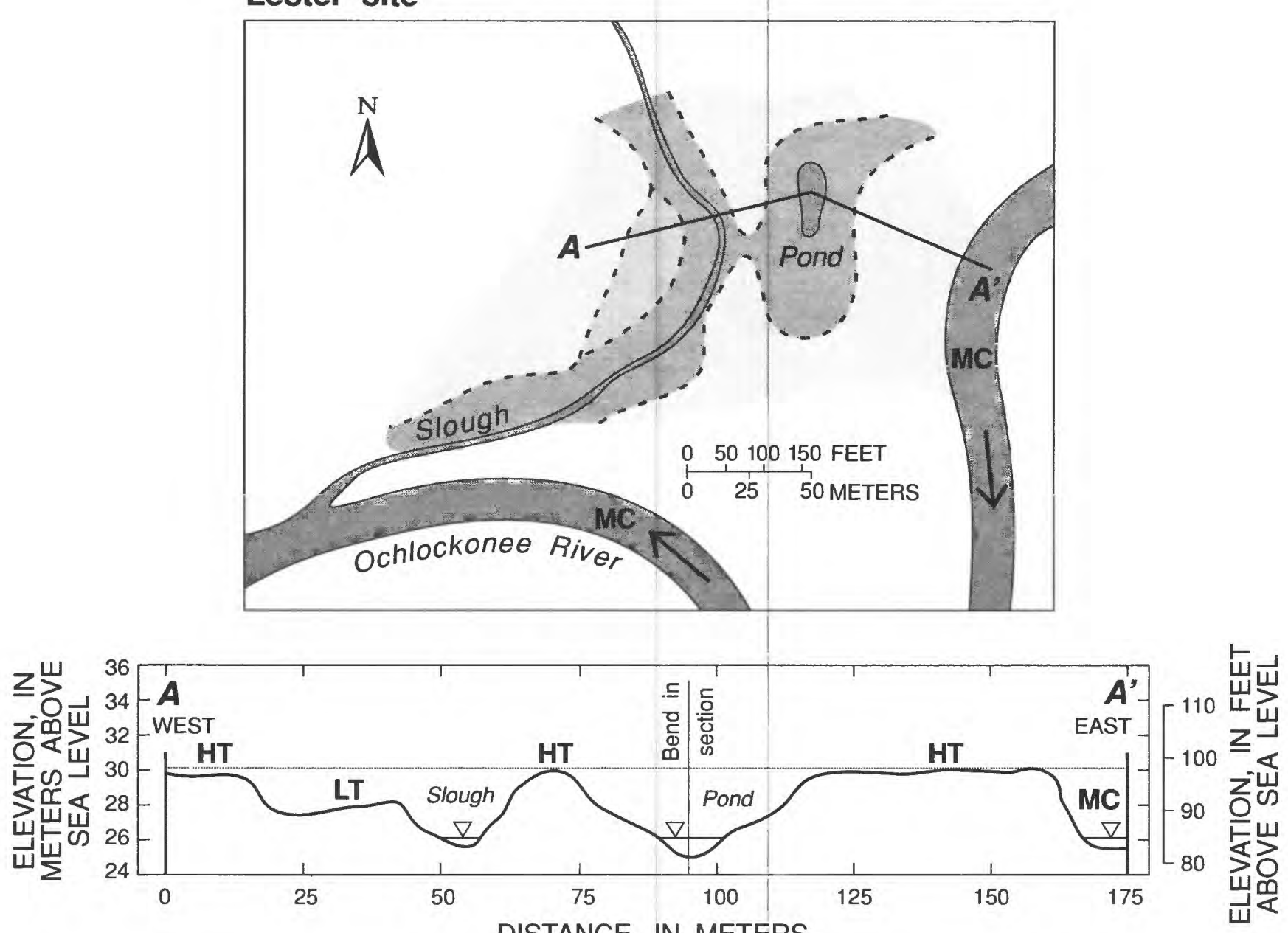

DISTANCE, IN METERS

Vertical exaggeration $\times 3.3$

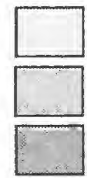

High terrace (HT)

Low terrace (LT)

EXPLANATION

Depression (D)

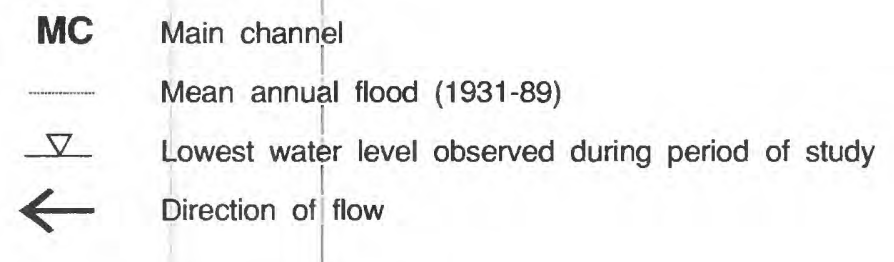

Figure 3. Approximate location and elevation of flood-plain features at the Lester site.

usually imperceptible (except after heavy local rains) because slough levels were controlled by backwater from the river most of the time. During drought, the slough partially dried up so that it was no longer connected to the river but still contained isolated pools. Immediately east of the slough the land rose steeply to another high terrace and then fell just as steeply to a pond on the other side. The pond at its lowest recorded level was slightly perched (by approximately 0.2 meters) above the water level in the main channel. During floods, water backed up from the river swelling the slough first, then filling the pond and surrounding depressions through a break in the intervening high terrace. East of the pond the land sloped up to a high terrace that extended to the riverbank.

The Old Bainbridge Road (OBR) site was located on the Gadsden County side of the river just east of a small tributary and approximately 150 meters upstream from its confluence with the main channel (fig. 4). The site was bounded on the north by a high terrace that dropped steeply to the largest pond sampled in this study. Unlike ponds at the other two sites, an opening in the forest canopy allowed direct sunlight to reach parts of the pond each day. The pond 


\section{Old Bainbridge Road site}
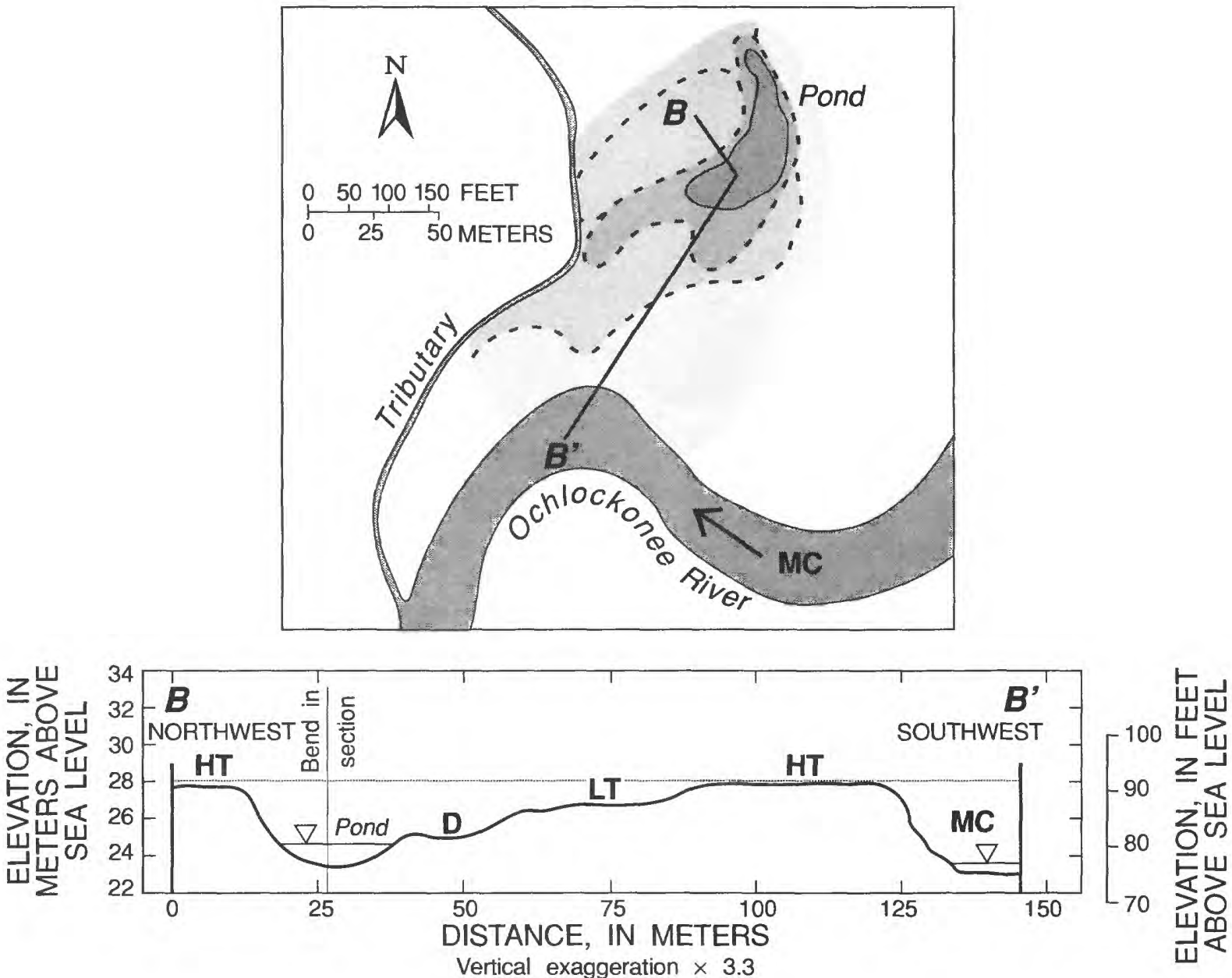

EXPLANATION

$\square$ High terrace (HT)
$\square$ Low terrace (LT)
$\square$ Depression (D)

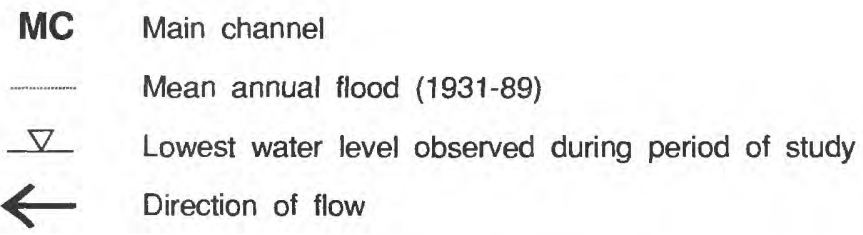

Figure 4. Approximate location and elevation of flood-plain features at the Old Bainbridge Road site.

at its lowest recorded level was perched almost a meter above the water level in the main channel. Elevations sloped gradually up from the pond to a cypress-tupelo depression, then to a low terrace, and finally to a high terrace that extended to the riverbank. A small berm on the bank of the tributary separated it from depressions at this site. During floods, water backed up from the river and swelled the tributary until the berm was breached, then filled the pond and depressions.

The site at the Ochlockonee River Wildlife Management Area (ORMA) was on the Leon County side just north of an upland bluff overlooking the river (fig. 5). Along the northeast base of the bluff was a swale-like depression vegetated with Ogeechee tupelo. Northeast of this depression was a pond surrounded on three sides by high terraces. The pond at its lowest recorded level was perched approximately 0.4 meter above the water level in the main channel. During floods, river water backed up into the swale-like depression first, then filled the pond when water was high enough to break over the intervening terrace. The high terrace northwest of the pond dropped steeply to a cypress-tupelo depression that was less than 5 meters from 


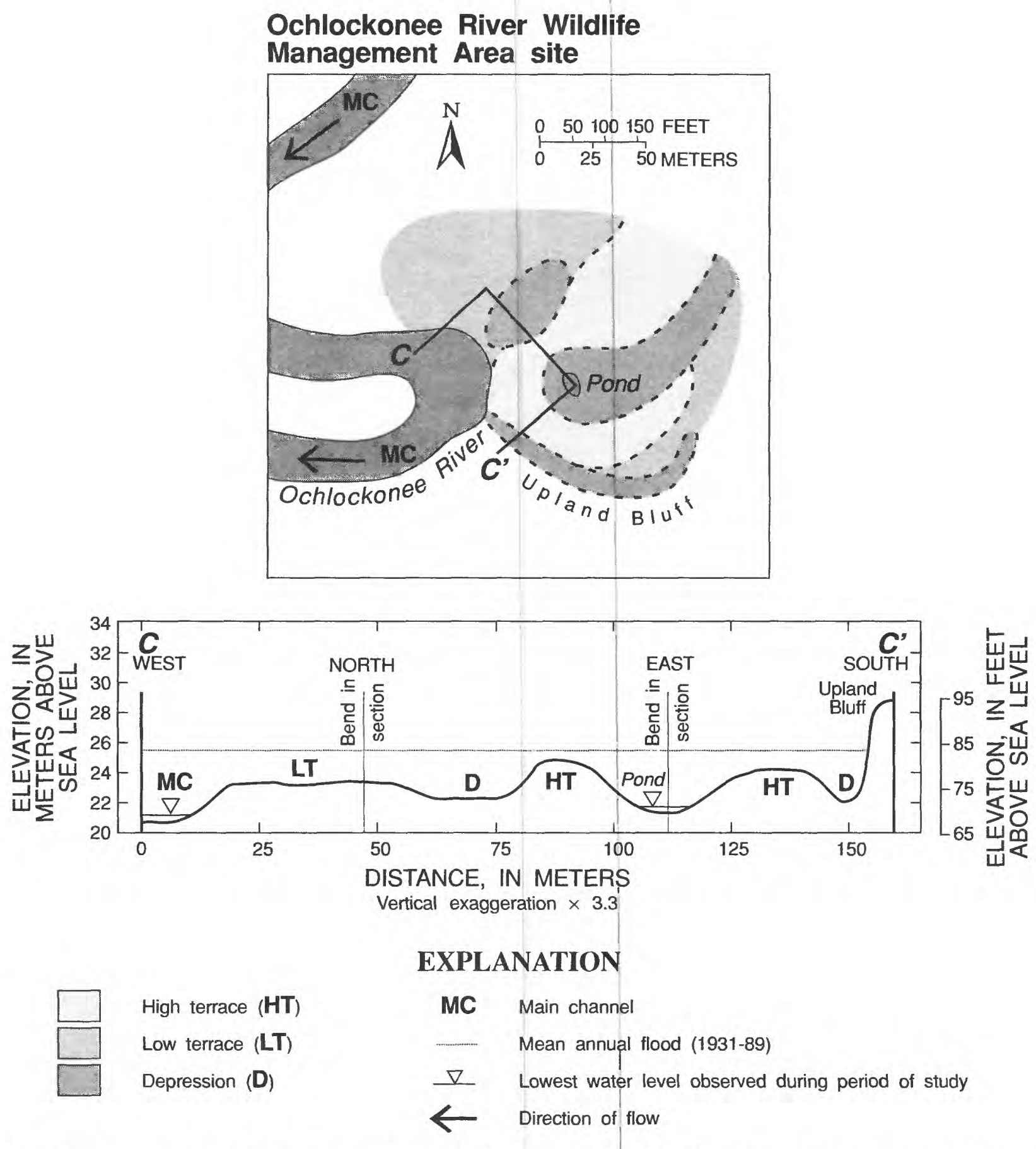

Figure 5. Approximate location and elevation of flood-plain features at the Ochlockonee River Wildlife Management Area site.

the main river channel and separated from it by a low berm. From there the land sloped gradually up into a low terrace to the northwest. Depressions sampled at this site were located closer to the main river channel than those at the other two sites.

Riverbank levees and high terraces at the study sites served as berms during low and medium stages, separating still-water habitats in ponds and depressions from the flowing waters of the main channel. Flood-plain ponds at all three sites may have been part of oxbow lakes at one time but were quite small in comparison with younger oxbows. The largest of the three ponds was at the OBR site. At its lowest recorded level it had a surface area of approximately $1,100 \mathrm{~m}^{2}$ (square meters) and a maximum depth of 1.2 meters. The Lester pond was second largest, with a surface area of approximately $250 \mathrm{~m}^{2}$ and a maximum depth of 1.2 meters at its lowest recorded level. The ORMA pond was smallest, with a surface area of approximately $65 \mathrm{~m}^{2}$ and a maximum depth of 0.3 meter at its lowest recorded level. In comparison, the recently formed oxbow lake which was a 
secondary sampling site in this study (fig. 2) was approximately $20,000 \mathrm{~m}^{2}$ in size. No trees or other terrestrial or emergent vegetation were growing in the ponds at their lowest levels. Filamentous algae was occasionally observed in the OBR and ORMA ponds when they were isolated from the river. When river stages were below the connecting level for flood-plain ponds and depressions, water levels in those areas fluctuated independently of the river in response to local rains, evapotranspiration, and ground-water seepage.

\section{METHODS OF INVESTIGATION}

This section describes the hydrologic, vegetation sampling, and fish sampling methods employed in the study. A combination of five different methods were used to sample fishes. The difficulties of sampling fishes in the flood plain are discussed.

\section{Hydrologic Methods}

The long-term gaging station, Ochlockonee River near Havana (02329000), is located at the U.S. Highway 27 bridge (fig. 2). This station, referred to as the Havana gage, has 59 years (1931-89) of available stage and discharge record (U.S. Geological Survey, 1931-89). It is currently (1990) a continuous recording gage, but prior to 1976 , an observer measured river stage once a day.

Main river channel levels were measured near each of the three flood-plain sites periodically during the study. Near the Lester site, a staff gage was installed on the main channel and an observer recorded river levels once a day from November 1987 to August 1989. Stage-to-stage ratings were developed by relating river stage at each of the three flood-plain study sites to river stage at the Havana gage. These ratings were used to estimate long term (1931-89) stage records at each of the three sites. Water-level measurements in isolated flood-plain pools and ponds were measured periodically to determine how flood-plain water level fluctuations differed from water levels in the main channel. Elevations above sea level for all water-level measuring points were established by surveying from the nearest known vertical-control benchmark.

Flood stage is used in this report to mean 20 feet gage datum at the Havana gage, which was the river level at which all flood-plain ponds, depressions, and low terraces at the study sites were connected to the river. Inundation of high terraces and riverbank levees required river stages of 24 to 25 feet gage datum. The mean annual flood stage (1931-89) is 26.7 feet gage datum.

Velocity was measured with a Price type AA current meter, or estimated by timing movement of entrained leaf fragments, at the flood-plain sites on an occasional basis during the study period. Velocity measurements have been made in the main channel at the Havana gage with a current meter several times a year throughout the period of record (1931-89). Dissolved oxygen was measured with a YSI Model $57^{1}$ oxygen meter in the flood plain on a quarterly basis during the study, with additional measurements made occasionally during the intervening periods

\section{Vegetation Sampling Methods}

Vegetation sampling plots ranging in size from 2,000 to $2,900 \mathrm{~m}^{2}$ were laid out at each of the three flood-plain sites. All canopy-size trees (more than 10 centimeters in diameter) on the plots were tagged with numbered aluminum tags, assigned to a topographic zone (high terrace, low terrace, or cypress-tupelo depression), identified to species, and measured for diameter at breast height (1.5 meters above the ground). Trees with swollen bases were measured for diameter above the swelling.

Line transects were established through the middle of each topographic zone on the plots. All subcanopy trees (2.5-10 centimeter diameter) in a 4-meter wide belt transect extending 2 meters on either side of the line transects were identified to species. All other vegetation (woody vegetation under 2.5 centimeter stem diameter and all herbaceous vegetation) intersecting an imaginary vertical plane along the line transect (line intercept method, Mueller-Dombois and Ellenberg, 1974) was identified to species, measured for horizontal extent along the line, and measured for height up to 1.5 meters. Dead vegetative matter was also measured by the line intercept method along line transects. The structure of both live and dead vegetative matter was quantified in this study. Amount of vegetative structure, in percent, is the area of the imaginary plane intersected by live or dead matter (height multiplied by extent along the line) divided by the total area of the plane (length of the line transect multiplied by 1.5 meters). Measurements of live and dead vegetation along line transects were made once before and once after the 1988 winter flood to characterize seasonal variation.

\section{Fish Sampling Methods}

A combination of five methods were used to sample flood-plain fishes: boat electrofishing, fyke nets, large wire traps, minnow traps, and dip nets. Pardue and Huish (1981) used a combination of several different methods to collect fishes in swamp streams in North Carolina. They found that sampling biases of individual methods were minimized, large numbers of all sizes of fishes were caught, and more species were collected than by any single method. Main channel fishes were collected in this study by boat electrofishing only.

Boat electrofishing samples were collected with one driver and one dipper using direct current (DC), with

\footnotetext{
${ }^{1}$ Use of the brand, firm, or trade names in this report is for identification purposes only and does not constitute endorsement by the U.S. Geological Survey.
} 
voltage, amperage, and pulse width adjusted for most efficient shocking. An aluminum boat was used as a cathode. The anode consisted of a ring configuration (Wisconsin style) with eight 12-millimeter diameter stainless steel droppers per ring, or a hand held 3.7-meter aluminum dip net. Fyke nets were modified 1.2-meter diameter hoop nets with 35 millimeter stretch mesh. Two 3.0-meter wings were attached to the first hoop and were set diagonally to the center line of the trap. Large wire traps, 1.2 meters long, 0.5 meter high, and 0.7 meter wide, with 13-millimeter bar mesh and two nested funnels (12 by 17 centimeter openings), were usually set without bait. Standard minnow traps of 6-millimeter bar mesh with funnels on each end (2.3-centimeter diameter openings) were usually set unbaited. (Minnow traps and large wire traps were baited with catfish bait three times in 1989 with no noticeable increase in catch.) Dip net samples were collected by sweeping a 45 -centimeter diameter dip net (4.8-millimeter bar mesh) through the water column.

Catch per unit effort (CPUE) values were calculated for fish collected by all methods. CPUE for electrofishing is defined as number of fish collected per minute of electrofishing time. CPUE for fyke nets, large wire traps, and minnow traps is defined as number of fish collected per trap (or net) per day. CPUE for dip netting is the number of fish collected per sweep of the net.

Fish sampling began October 1987 and continued through August 1989. Sampling dates in relation to water levels are shown in figure 6. The two years of the study period were quite different hydrologically, requiring a shift in sampling strategy from one year to the next. The first year, most of the flood-plain sampling was conducted with boat electrofishing, fyke nets, and minnow traps for the purpose of documenting the presence of fishes in the flood plain during floods. During the first half of the second year, water levels were unusually low and flood-plain collections were made primarily with traps and dip net to sample flood-plain ponds that were isolated from the river. Lack of boat access prevented flood-plain electrofishing during the drought except in the slough at the Lester site. Flooding in the second year did not occur until June, at which time fyke nets were set again and more extensive flood-plain electrofishing was conducted. For each flood-plain fish sampling date and location, a determination was made of the length of time the sampling location had been continuously isolated or connected to the river.

Most fish were identified in the field, grouped into 20 millimeter size classes (to speed up the handling process), weighed, and then released. Reproductive condition was noted for fish in spawning colors, swollen individuals, flowing males, and ripe females.

The difficulties of sampling fish in the seasonally inundated flood plain were many. The volume of water during floods was so great that the only effective methods were those that covered large areas (boat electrofishing) or partially concentrated the fish (fyke nets with wings). Wegener rings (Wegener and others, 1973) and backpack electrofishing were attempted during floods and caught very few fish. The highly variable topography in the flood plain also made backpack electrofishing dangerous. Water depths during floods required the use of boats for safety purposes; however, obstructions such as trees, shrubs, riverbank levees, and high terraces in the flood plain restricted maneuverability. During low water periods, boat access was impossible and sampling gear had to be relatively small for transport on foot to isolated flood-plain ponds. All the ponds had very soft, organic bottoms during the drought, which prevented the use of seines or other sampling methods that required wading. Lethal collection methods such as rotenone and gill nets were not used in the ponds because continued sampling throughout the drought was desired. Several hooks set with catfish bait in the OBR pond produced no fish.

\section{HYDROLOGY OF RIVER AND FLOOD PLAIN}

Mean monthly river stages for the 2 years of study, 1988 and 1989, compared to those for 59 years of record from 1931 to 1989 are shown in figure 7. The annual flood season typically occurs in January, February, March, and April with highest water levels occurring in February and March. Lowest water levels are typically in October and November. The 24-month period of study from October 1987 to September 1989 included 9 months that were 2.3 to 7 feet lower than long-term mean river stage (June, July, and August, 1988; and December 1988 through May 1989). Ten additional months were lower than long-term means by 2 feet or less. The 2-year study period included only 5 months in winter 1988 and summer 1989 that were above long-term means. Flood patterns in 1989 were unusual in that the first flood of the year exceeding 20 feet gage datum occurred in summer (June- July) rather than in winter and spring. Examination of historical records showed that summer floods of more than 20 feet gage datum have been quite common, occurring in more than half of the 59 years from 1931 to 1989 . However, they were usually of shorter duration than winter-spring floods and nearly always followed a wet winter-spring season. In only 4 of 59 years (1935, 1957, 1985, and 1989) did the highest annual flood occur in summer with no flooding in the preceding winter or spring. Unusual flooding patterns occurred in only 3 other years. In 1934 and 1968 there was no flood for the entire year that exceeded 20 feet gage datum, and in 1938 the annual flood occurred in fall.

Lower than normal river stages in summer and fall in 1988 , and delayed annual flooding in 1989 , caused most of the flood-plain features at two of the study sites to be continuously isolated from the river for 13 to 14 months. The Lester pond was connected briefly iil late March and early April 1989 after being isolated from the river continuously for 10 months. Droughts of this length or longer occurred only four other times during the period of record, twice in the 1930's, once in the mid-1950's, and once in the late 1960's. 


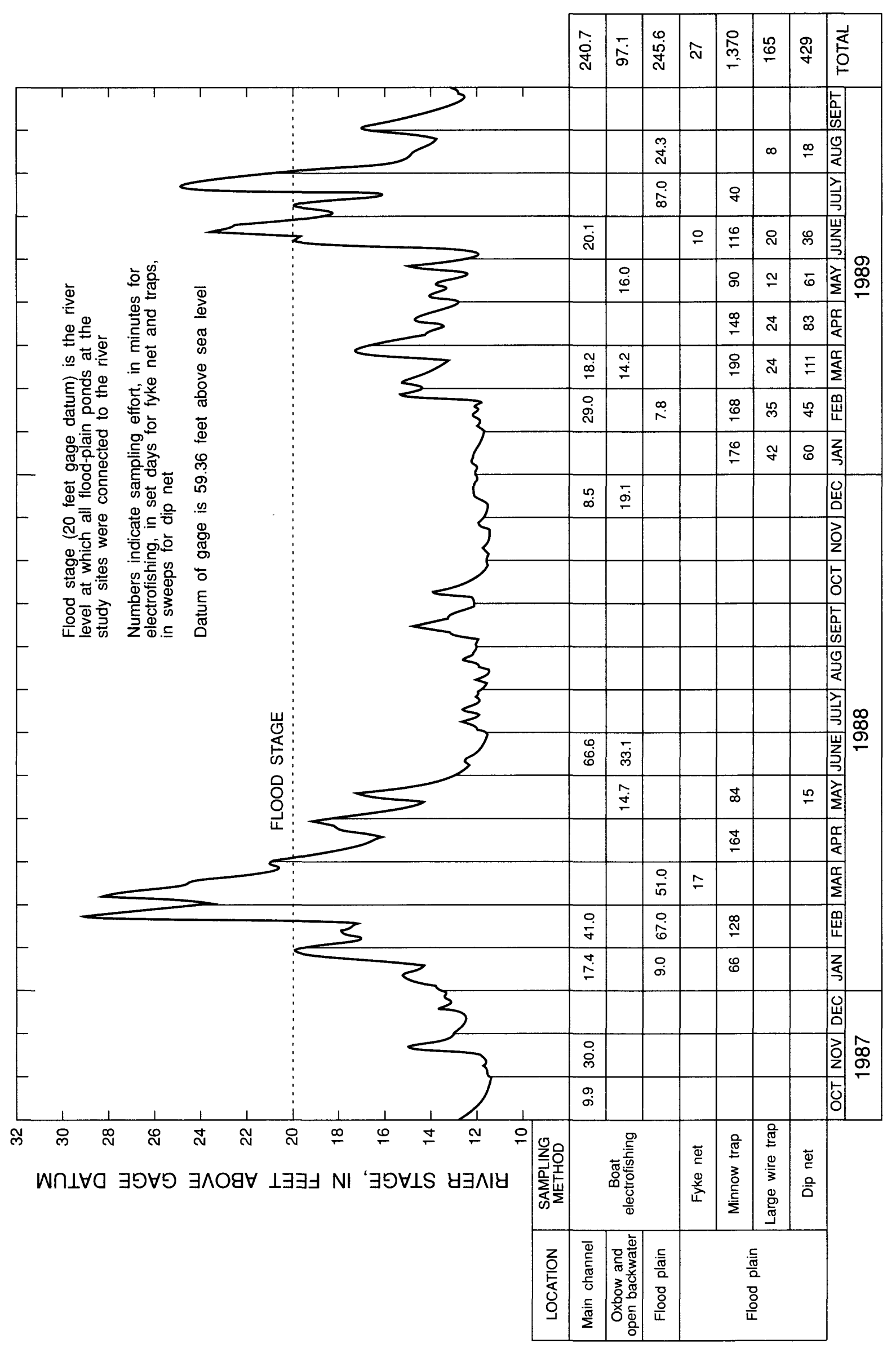

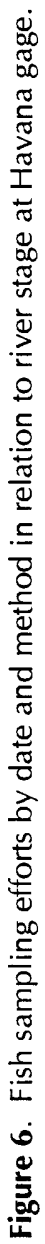




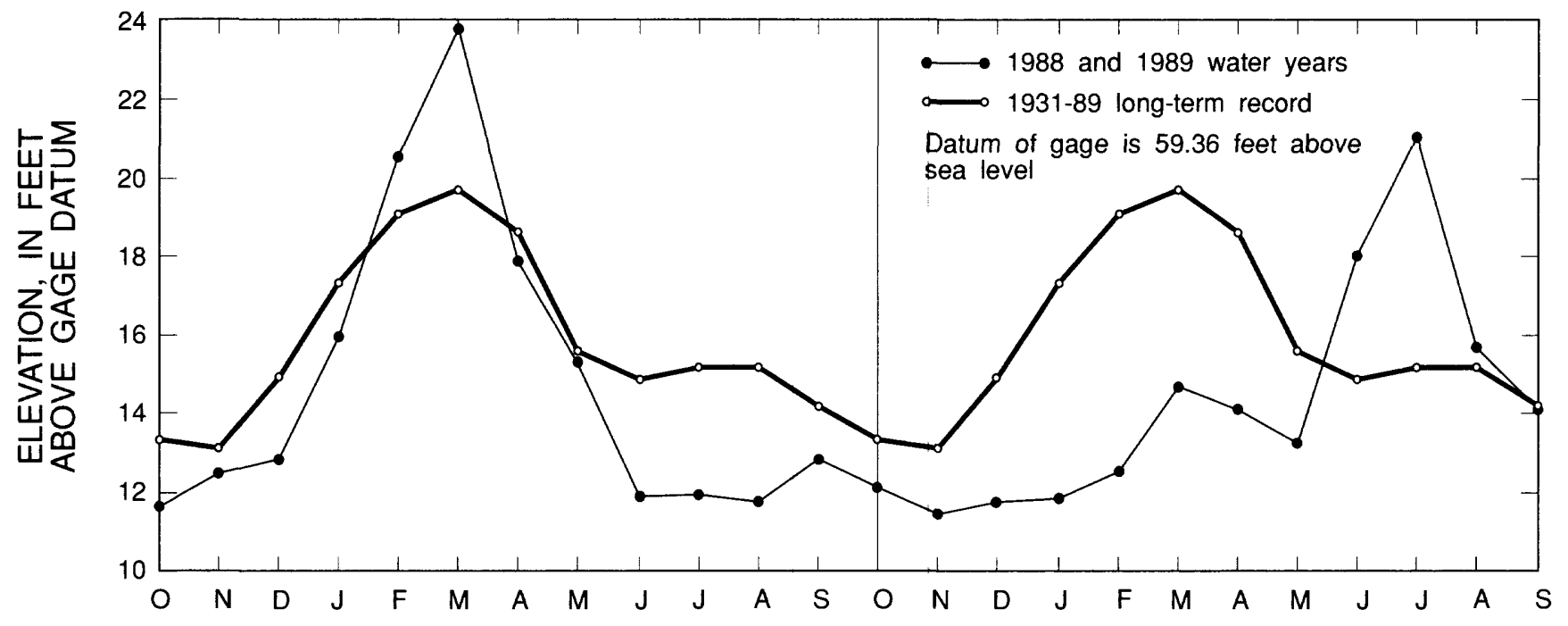

Figure 7. Mean monthly river stage for 1988 and 1989 water years and long-term record (1931-89) at Havana gage.

Availability of the flood plain to fishes that typically inhabit the main river channel is dependent on frequency and duration of floods that connect the river to the flood plain. Flooding allows river fishes the opportunity to use the flood plain for spawning and nursery grounds as well as a source of food and cover. The shorter the flood duration the less likely the flood plain will be usable by most species for spawning and nursery functions. However, floods of any duration increase the amount of food and protective cover for fishes. The percentage of time during the 2-year study and during the period of record (1931-89) that flood-plain features at each of the study sites were flooded by or connected to the river is given in table 1. Long-term record indicates that high terraces were flooded an average of 2 to 3 weeks a year. Low terraces were normally flooded a total of 2 to 4 months of the year (not necessarily consecutive). Depressions were typically flooded by the river a total of 3 to 5 months of the year, but water was often trapped in these areas long after floods receded. Flood durations during the study were shorter than historical durations for all flood-plain features, reflecting the drought conditions that were prevalent during this study.

Maximum velocities measured in the main channel at the Havana gage were 1-1.5 ft/s (foot per second) during low stages (11-15 feet above gage datum) and $2-3 \mathrm{ft} / \mathrm{s}$ at high stages (20-25 feet above gage datum). Measured velocities in the flood plain were lower, usually negligible at low and medium stages and as much as $0.5 \mathrm{ft} / \mathrm{s}$ at high stages. Variable velocities of as much as $1.5 \mathrm{ft} / \mathrm{s}$ were measured in the flood plain at a very high stage ( 29 feet above gage datum) in February 1988. There was no perceptible velocity in the oxbow or open backwater at the low and medium stages during which sampling was conducted.

The Ochlockonee River flood plain contains both lentic (still water) and lotic (flowing water) habitats that are sometimes isolated and sometimes connected. During high
Table 1. Percentage of time flood-plain features were flooded by or connected to the river during the study and over a long period of record (1931-89)

[OBR, Old Bainbridge Road; ORMA, Ochlockonee River Wildlife Management Area]

\begin{tabular}{c|cc} 
Site & $\begin{array}{c}\text { Flood-plain } \\
\text { feature }\end{array}$ & $\begin{array}{c}\text { Percentage of time during indicated } \\
\text { period feature was flooded by or } \\
\text { connected to river } 1,2\end{array}$ \\
& & $\begin{array}{c}1988 \text { and } 1989 \\
\text { water years } 1931-89\end{array}$ \\
\hline
\end{tabular}

$\begin{array}{llrr}\text { OBR } & \text { High terrace } & 2 & 4 \\ \text { Lester } & \text { High terrace } & 4 & 6 \\ \text { ORMA } & \text { High terrace } & 4 & 7 \\ \text { OBR } & \text { Low terrace } & 8 & 16 \\ \text { ORMA } & \text { Pond }^{3} & 10 & 18 \\ \text { ORMA } & \text { Low terrace }_{\text {OBR }} & \text { Cypress-tupelo depression } & 3 \\ \text { OBR } & \text { Pond }^{3} & 14 & 24 \\ \text { Lester } & \text { Low terrace } & 14 & 24 \\ \text { ORMA } & \text { Cypress-tupelo depression }^{3} & 18 & 30 \\ \text { OBR } & \text { Tributary }^{3} & 22 & 31 \\ \text { Lester } & \text { Cypress-tupelo depression }^{3} & 26 & 41 \\ \text { Lester } & \text { Pond }^{3} & 26 & 41 \\ \text { ORMA } & \text { Swale-like depression }^{3} & 26 & 41 \\ \text { Lester } & \text { Slough }^{3} & 51 & 68\end{array}$

${ }^{1}$ Represents the total amount of time that river stage was at or above: (1) the median elevation of terraces, (2) the elevation of river connection levels for ponds and depressions, and (3) the elevation at which sloughs and tributaries were backed up by the river. River stage records at each of the study sites were estimated from Havana gage records.

${ }^{2}$ Caution should be used in converting percentage of time to days per year. Days per year computed by this method are the total (not consecutive) days of flooding. They represent the average over the period of years indicated, and actual days per year of flooding in any given year could be quite different from this average.

${ }^{3}$ Because of their depressional shape, water is trapped in these areas sometimes long after floods recede. The durations given above indicate only the amount of time that these areas are connected to the river and do not reflect the additional time that water stands in them after they become isolated from the river. 
floods, all areas of the flood plain are lotic, although velocities are usually much lower in the flood plain than in the main channel. The most isolated water body was the pond at the ORMA site, which was connected to flowing water only 18 percent of the time for the 1931-89 period of record (table 1). The flood-plain site at OBR included a permanently lotic feature, a tributary with an upland drainage basin that continued to flow throughout the drought.

\section{VEGETATION IN FORESTED FLOOD PLAIN}

Forest types in the various topographic zones of flood plains are strongly influenced by the diverse hydrologic conditions of those zones (Larson and others, 1981; Wharton and others, 1982; Leitman and others, 1983). On the Ochlockonee River flood plain, tree communities were distinct in each topographic zone, reflecting the varied hydrologic conditions of the flood-plain features shown in table 1.

\section{Plant Communities}

Canopy trees of the high terraces with relative basal areas greater than 15 percent were spruce pine, sweetgum, live oak, and water oak (table 2). Common subcanopy species (with relative densities greater than 10 percent) were

Table 2. Canopy tree species on high terraces, low terraces, and cypress-tupelo depressions

\begin{tabular}{|c|c|c|c|}
\hline \multirow[b]{2}{*}{ Species $^{I}$} & \multicolumn{3}{|c|}{ Relative basal area, in percent } \\
\hline & $\begin{array}{l}\text { High } \\
\text { terraces }\end{array}$ & $\begin{array}{c}\text { Low } \\
\text { terraces }\end{array}$ & $\begin{array}{c}\text { Cypress- } \\
\text { tupelo } \\
\text { depressions }\end{array}$ \\
\hline Sparkleberry & 0.6 & & \\
\hline Ironwood & 1.3 & & \\
\hline Swamp tupelo & 4.9 & & \\
\hline American holly & 7.8 & & \\
\hline Water oak & 15.8 & & \\
\hline Live oak & 16.1 & & \\
\hline Spruce pine & 22.6 & & \\
\hline Possum-haw & & 0.3 & \\
\hline River birch & & 1.1 & \\
\hline Sweetgum & 20.3 & 8.2 & 1.8 \\
\hline Swamp laurel oak & 5.6 & 56.3 & \\
\hline Red maple & 1.3 & 20.2 & 1.2 \\
\hline Overcup oak & & 4.5 & \\
\hline Bald-cypress & 3.6 & 2.4 & 27.1 \\
\hline Ogeechee tupelo & .4 & 6.3 & 58.4 \\
\hline Planer-tree & & .5 & 5.8 \\
\hline Carolina ash & & .2 & 4.8 \\
\hline May haw & & & .8 \\
\hline Total: & 100.3 & 100.0 & 99.9 \\
\hline Area of zones, in hectares: & .145 & .147 & .224 \\
\hline $\begin{array}{l}\text { Basal area, in square meters } \\
\text { per hectare: }\end{array}$ & 50.6 & 42.9 & 44.5 \\
\hline
\end{tabular}

\footnotetext{
${ }^{1}$ Grouped by topographic zones.
}

possum-haw, sweetgum, American holly, sparkleberry, ironwood, and muscadine. Forked panicum and spikegrass contributed more than 10 percent of total ground cover in spring-summer; sedges and poison-ivy were the next most common ground cover species. High terraces had more total ground cover vegetation ( 59 percent cover of line transects in spring-summer) than either low terraces (13 percent) or cypress-tupelo depressions (10 percent). The noted increase in ground cover vegetation with increasing elevation is probably due to shorter periods of inundation (table 1) and shallower flood depths at higher elevations.

Low terraces were dominated by a canopy of swamp laurel oaks at all sites. Red maple had the next greatest relative basal area. The subcanopy was dominated by different species at each site with possum-haw and Carolina ash the most common species overall. Ground cover on the low terraces was sparse with ladies' eardrops (a vine) and redtop panicum the most common species.

Ogeechee tupelo dominated the canopy of cypress-tupelo depressions at all three sites. Bald-cypress was the most important associate tree species. In the subcanopy Carolina ash strongly dominated all sites. Ground cover was very sparse with redtop panicum and ladies' eardrops the most common species.

\section{Vegetative Structure}

The amount of live and dead vegetative structure up to 150 centimeters above ground level varied with topographic zone and season (fig. 8). Live structure included herbaceous

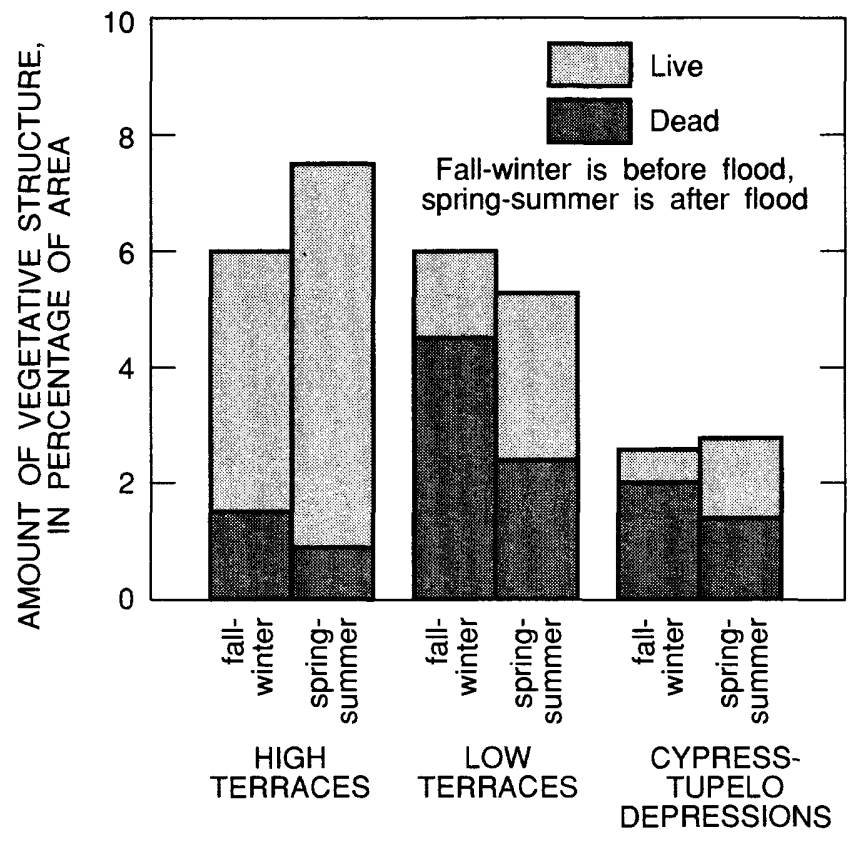

Figure 8. The amount of live and dead vegetative structure up to 150 centimeters above ground level in fall-winter (before flooding) and spring-summer (after flooding). 
and woody plants and tree trunk bases. Dead vegetative structure included leaf litter, branches, limbs, and rotten logs, which are derived mostly from the canopy trees. High and low terraces have the greatest amount of total vegetative structure. Although cypress-tupelo depressions had less structure, flood durations (table 1) indicate that they are available to fishes for longer periods of time. Isolated ponds provided permanent aquatic habitat in the flood plain but did not contain trees or other emergent vegetative structure (submerged structure in ponds was not measured).

Two species of panic grasses, forked panicum and redtop panicum, accounted for more than one-fifth of all live vegetative structure encountered on the line transects and were found in all topographic zones studied. In particular, redtop panicum with its large clumps of dead stalks and leaves that persist through the winter-spring flood season, provided one of the most likely sources of protective cover for fishes provided by live vegetation.

Although high terraces supported the greatest amount of live vegetative structure, they had the least amount of debris, probably because removal of debris by floodwaters on high terraces may have been greater than in lower zones. Velocities in the flood plain appeared to be sufficient to move debris when water levels were above the high terraces. Velocities slowed significantly when water levels fell below the elevation of high terraces which may have caused more debris to settle in low terraces and depressions. The steep slopes grading down from high terraces may also account for the larger amount of debris in the lower zones as most limbs falling on slopes accumulate at the bottom. Amount of dead vegetative structure decreased after flooding in all three zones, indicating that much of the accumulated debris on the flood plain may have been washed off in the 1988 winter flood.

\section{RIVER-FLOOD-PLAIN FISHES}

A total of 8,225 fishes belonging to 15 families and 48 species were collected during the 2-year study in various habitats in the Ochlockonee River and flood plain (appendix I). Eighty-one percent of the fishes belonged to two families, minnows and carps (Cyprinidae) and sunfishes (Centrarchidae). The most common species by number (in descending order) were weed shiner, redbreast sunfish, blacktail shiner, bannerfin shiner, and bluegill. According to biogeographic studies by Swift and others (1986), the fish fauna of the Ochlockonee River basin is nearly identical to fish faunas of the Suwannee River basin and intervening drainages. In that study, Ochlockonee fishes were reported to be more similar to those of streams to the east, northeast, and southeast (up to the Savannah River and including peninsular Florida streams) than they were to the fishes of the adjacent Apalachicola River basin and other drainages to the west.

Four minor species listed in appendix I are not native to this river system. A single green sunfish was collected in the tributary at the OBR site. This introduced species is new to the Ochlockonee River system in Florida; however, three specimens were collected previously in Georgia in the main channel of the Ochlockonee River, two of which were caught near the Florida State line (Keefer and Ober, 1977; Ober and Keefer, 1983). This species was originally found from the Great Lakes region southward to Mexico and has been widely introduced elsewhere in the United States (Lee and others, 1980). Other introduced species are white bass, first reported in the Ochlockonee River in 1984 (D.A. Dobbins, Florida Game and Fresh Water Fish Commission, oral commun., 1989), common carp, first recorded in the Ochlockonee River below Lake Talquin in 1974 (Swift and others, 1977), and clear chub, first collected in a tributary that drains into Lake Talquin in 1967 (Swift and others, 1977).

One other species that deserves mention is the Suwannee bass, a species of special concern to the FGFWFC (Wood, 1988). It is the only species collected in this study that has official designation as endangered or potentially endangered.

\section{Fishes in Flood Plain During Flood Conditions}

Thirty-seven species of fish were collected in the flood plain during flood conditions (table 3 ). Based on combined catches resulting from five different sampling methods, the most frequently collected species in the flood plain during floods (in order from most to least common) were weed shiner, redbreast sunfish, brown bullhead, bluegill, gizzard shad, mosquitofish, and redear sunfish. All seven species have been collected on inundated flood plains of other rivers in the eastern United States (Holder, 1971b; Bass and Hitt, 1973; Guillory, 1979; Ross and Baker, 1983; Walker and Sniffen, 1985; Finger and Stewart, 1987; and Kwak, 1988). Four of these species were among the most abundant flood-plain taxa reported in Mississippi and Louisiana: weed shiner, bluegill, mosquitofish (Ross and Baker, 1983), and gizzard shad (Guillory, 1979). Redbreast sunfish was the most abundant species collected in the flood plain of the Santa Fe River in Florida (Bass and Hitt, 1973).

Electrofishing and fyke net collections yielded the greatest number of species and individuals; however, five additional species collected by minnow traps and dip nets were not caught by the two most effective methods. A wide range of sizes of fish was caught by electrofishing whereas a limited and in some cases exclusive size range of fish was caught by each type of net and trap. (Average weights and median lengths collected by each method are summarized in appendix I.) All methods showed an apparent bias toward certain species or families of fish. Ninety-seven percent of the shiners (Cyprinidae) were collected by electrofishing, in addition to nearly all the shad, brook silverside, and largemouth bass (table 3). Ninety-eight percent of the catfish, all the white bass, and most of the black crappie were collected in fyke nets. Three centrarchids, redbreast 
Table 3. Fishes collected in the Ochlockonee River flood plain during flood conditions ${ }^{1}$ by five different methods

[Sampling was conducted from January 1988 through August 1989. Datum of gage is 59.36 feet above sea level; $\mathrm{mm}$, millimeters]

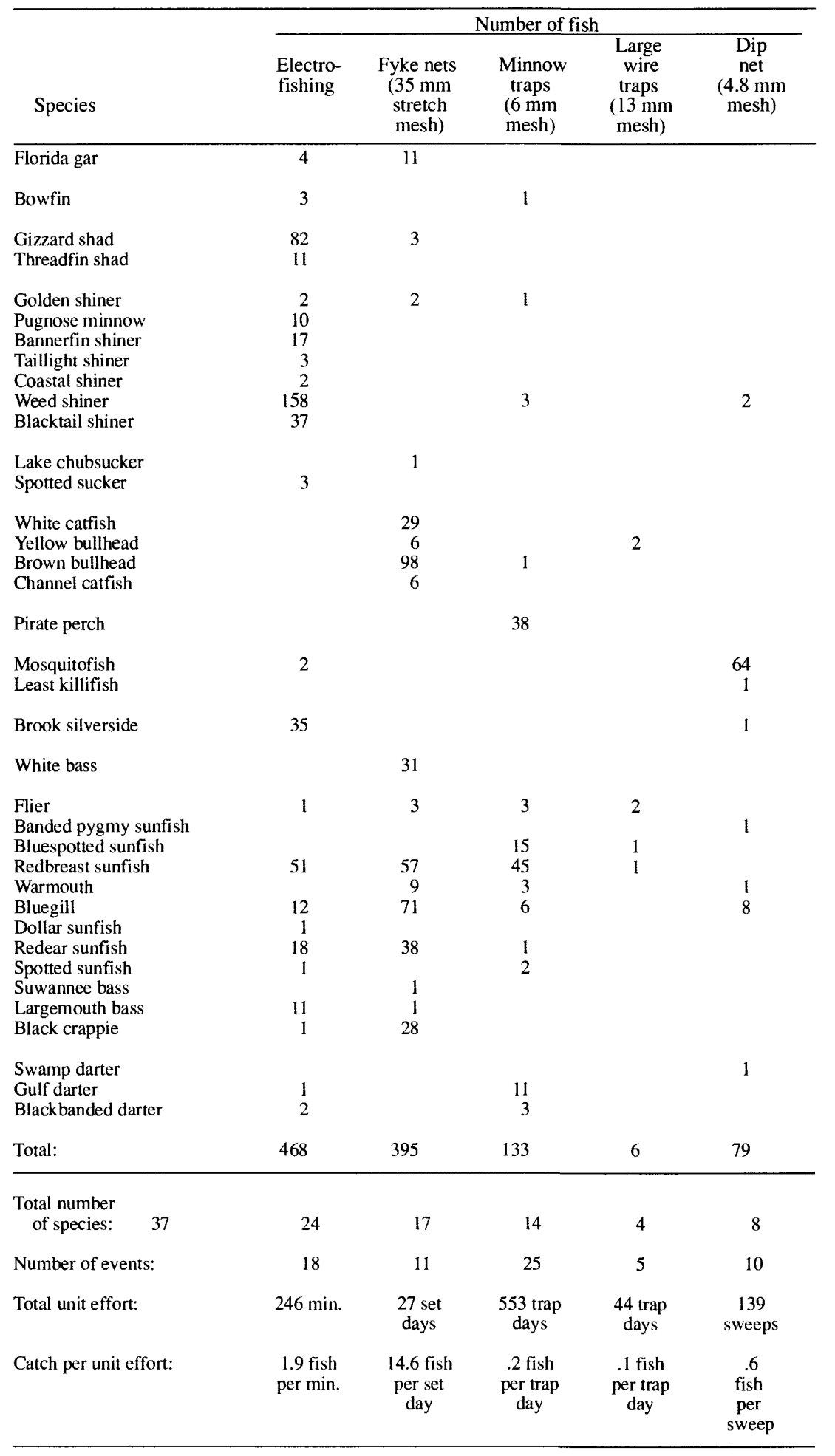

'The river stage considered to be "flood conditions" varied substantially from one location to the next. The river moved first into sloughs and tributaries at stages from 14.5 to 16.5 feet gage datum, causing them to swell considerably into adjacent cypress-tupelo swamps. Ponded areas in the flood plain were connected to the river at various stages ranging from 15.5 to 20 feet gage datum. The high terrace forests at the sites were flooded at about 24 to 25 feet gage datum. 
sunfish, redear sunfish, and bluegill, were commonly collected by more than one method.

Pirate perch and bluespotted sunfish were collected in the flood plain during floods exclusively by traps (table 3 ). Pirate perch made up 51 percent of the total number of fish collected by traps and nets on the inundated flood plain of Creeping Swamp, N.C. (Walker and Sniffen, 1985), and was the most abundant species collected by backpack electrofishing and rotenone in another North Carolina swamp stream (Pardue and Huish, 1981). This species was commonly collected on inundated flood plains of the upper Suwannee River, Ga., (Holder, 1971b), the lower Mississippi River (Guillory, 1979), the Kankakee River, Ill. (Kwak, 1988), and the Cache River, Ark. (J.A. Baker, U.S. Army Corps of Engineers, oral commun., 1990).

Ninety-seven percent of the mosquitofish (table 3) were collected by dip netting. Mosquitofish swim on the surface near the water's edge in a wide variety of habitats (Swift and others, 1977). They were dip netted more often than any other species because they were so highly visible. Least killifish and banded pygmy sunfish were collected by dip net only. Both of these species were too small to be caught in minnow traps. Mosquitofish and least killifish dominated small fish collections on the seasonally inundated marshes of the Kissimmee River flood plain in central Florida (Milleson, 1976). Banded pygmy sunfish comprised 70 percent of the larval, juvenile, and small adult fishes sampled with activity traps in seasonally flooded lowland hardwoods in southeastern Missouri (Finger and Stewart, 1987).

\section{Fishes in Flood Plain During Drought Conditions}

Thirteen species of fishes were observed or collected with traps or dip nets in flood-plain ponds that had been continuously isolated from the river for 8 to 13 months (table 4). Based on combined catches from all three methods, flier, pirate perch, mosquitofish, and warmouth were the most common species collected in the drought ponds. Seven species were collected in ponds at all three sites, including the ORMA pond which was quite small and shallow $\left(65 \mathrm{~m}^{2}\right.$ surface area and 0.3 meter deep). Five remaining species were collected, and Florida gar were observed, only at the largest pond at the OBR site $\left(1,100 \mathrm{~m}^{2}\right.$ surface area and 1.2 meters deep). Greater species richness in the largest pond substantiates the findings of Halyk and Balon (1983) who reported an exponential increase in number of species with increasing area for small flood-plain pools in southern Ontario. Species richness appeared to decline in the smallest pond (ORMA) in the last 3 months of the drought. Seven species were collected there in January and early February of 1989, 3 species in late February and March, and only 2 species, pirate perch and mosquitofish, were sampled in May 1989, the 13th month of the drought. There was no evidence of a decline in number of species over time at the two largest ponds (OBR and Lester). Survival of these
Table 4. Fishes collected in isolated ponds of the Ochlockonee River flood plain during drought conditions by three different methods

[Sampling was conducted from January through May 1989 in flood-plain ponds that had been continuously isolated from the river for 8 to 13 months. Florida gar were observed but not collected in a pond at the Old Bainbridge Road site that had been continuously isolated from the river for 12 months. $\mathrm{mm}$, millimeters]

\begin{tabular}{|c|c|c|c|}
\hline \multirow[b]{2}{*}{ Species } & \multicolumn{3}{|c|}{ Number of fish } \\
\hline & $\begin{array}{c}\text { Minnow } \\
\text { traps } \\
(6 \mathrm{~mm} \\
\text { mesh) }\end{array}$ & $\begin{array}{l}\text { Large } \\
\text { wire } \\
\text { traps } \\
(13 \mathrm{~mm} \\
\text { mesh) }\end{array}$ & $\begin{array}{c}\text { Dip } \\
\text { net } \\
(4.8 \mathrm{~mm} \\
\text { mesh }) \\
\end{array}$ \\
\hline Redfin pickerel & 2 & 5 & \\
\hline Taillight shiner ${ }^{1}$ & 45 & & \\
\hline Pirate perch & 77 & 7 & 5 \\
\hline Mosquitofish & 1 & & 86 \\
\hline Least killifish ${ }^{\prime}$ & & & 11 \\
\hline Flier & 16 & 146 & 2 \\
\hline Banded pygmy sunfish & 1 & & 38 \\
\hline Bluespotted sunfish & 12 & & \\
\hline Warmouth & 51 & 20 & 13 \\
\hline Bluegill $^{1}$ & 27 & 13 & 1 \\
\hline Dollar sunfish ${ }^{\prime}$ & & 1 & \\
\hline Black crappie ${ }^{l}$ & 3 & 3 & 1 \\
\hline Total: & 235 & 195 & 157 \\
\hline $\begin{array}{l}\text { Total number } \\
\text { of species: }\end{array}$ & 10 & 7 & 8 \\
\hline Number of events: & 23 & 14 & 15 \\
\hline Total unit effort: & $\begin{array}{l}439 \text { trap } \\
\text { days }\end{array}$ & $\begin{array}{l}82 \text { trap } \\
\text { days }\end{array}$ & $\begin{array}{c}142 \\
\text { sweeps }\end{array}$ \\
\hline Catch per unit effort: & $\begin{array}{c}.5 \text { fish } \\
\text { per trap } \\
\text { day }\end{array}$ & $\begin{array}{c}2.4 \text { fish } \\
\text { per trap } \\
\text { day }\end{array}$ & $\begin{array}{l}\text { l.I fish } \\
\text { per } \\
\text { sweep }\end{array}$ \\
\hline
\end{tabular}

${ }^{1}$ Collected in Old Bainbridge Road pond only. (All other species were collected in ponds at all three sites.)

species in the flood plain through a longer drought may depend on pond size to some extent.

All thirteen species collected or observed in drought ponds (table 4) survived surface dissolved-oxygen concentrations as low as 0.6 to $0.8 \mathrm{mg} / \mathrm{L}$ in the preceding fall. Thirteen of 15 surface dissolved-oxygen measurements made in flood-plain ponds and depressions in late spring, summer, and fall were below $2.0 \mathrm{mg} / \mathrm{L}$. (Surface measurements, taken at depths of 8 to 15 centimeters, were always higher than middepth and bottom dissolved-oxygen concentrations when they were measured.) Although there is a wide range in reported tolerance levels, there is general agreement that concentrations less than 5 or $6 \mathrm{mg} / \mathrm{L}$ are unfavorable for long-term growth and survival of fishes (Moore, 1942; Jones, 1964; Petit, 1973; Davis, 1975). However, most of these authors reported on studies that were conducted in cool temperate regions and these results may not be useful for predicting tolerance levels in warm temperate areas. Dissolved-oxygen concentrations between 
2 and $4 \mathrm{mg} / \mathrm{L}$ are a periodic natural occurrence in many Florida streams and swamps (Dierberg and Brezonik, 1984; Friedemann and Hand, 1989; Hampson, 1989). Kramer and others (1978) noted that temperate fishes are much more sensitive to hypoxia than tropical fishes. They reported that deleterious oxygen concentrations reported by Davis (1975) for Canadian species $(2.3 \mathrm{mg} / \mathrm{L})$ were well above those probably experienced by many Amazonian fishes for days or even months at a time. Research on geographic variations of tolerance levels would be helpful to determine if fishes in the warm temperate climate of north Florida are more acclimated to low dissolved oxygen than the same species of fishes in cooler temperate regions.

The most effective methods for collecting fishes during floods, electrofishing and fyke nets, required boat access and could not be used during the drought. Quantitative comparisons of fishes collected during floods (table 3 ) to those caught in drought ponds (table 4) are limited to trap and dip net collections. Although the number of individuals collected by these methods was much higher in drought ponds (587) than during flood conditions (218), the number of species that could tolerate adverse conditions in the drought ponds was relatively limited (12 species collected by traps and dip nets in the drought ponds compared with 20 species collected by the same methods during floods). One species, redbreast sunfish, that was commonly collected by minnow traps on the inundated flood plain was never collected by traps in the drought ponds, suggesting that it either returns to the river as floodwaters recede or succumbs to the adverse conditions of the ponds. Gulf darter collections indicated a similar intolerance of drought pond conditions, although sample sizes were smaller. Darters as a group generally inhabit flowing waters (Kuehne and Barbour, 1983), and it is unlikely that either Gulf darters or blackbanded darters could survive in these isolated ponds. Swamp darter, with its preference for still water and its tolerance for low oxygen concentrations (Swift and others, 1977; Kuehne and Barbour, 1983), may have been able to survive in the drought ponds. However, it does not appear to be very common in this river system (appendix I).

The taillight shiner, which is known to prefer soft bottoms in backwaters and lakes (Swift and others, 1977), was the only species of Notropis collected in the drought ponds (table 4). Because traps and dip nets were not effective sampling methods for collecting shiners as a group, there may have been other species of Notropis present that were not collected. Even taillight shiners were not sampled well by these methods, despite the fact that they made up a significant proportion of the minnow trap collections in the drought ponds. All 45 taillight shiners collected in drought ponds were collected in two sampling events (late April and late May 1989). All exhibited breeding colors, and the vast majority (91 percent) were caught in a single trap during a single 3-day event. Other common species in the drought ponds were collected much more frequently and consistently. For example, warmouth, collected by minnow traps in slightly higher numbers than taillight shiner. were raught in 26 different trap settings during 11 sampling events in all 5 months of the drought sampling period (January through May 1989). Minnow traps are effective in catching small fish species; however, the strong seasonal variation in taillight shiner collections indicates that minnow traps have limitations when used to estimate fish populations. He and Lodge (1990) reported that placement of the traps and species interactions also affected minnow trap catches.

Two catfish species that may have been able to survive in the drought ponds but were not collected there were brown bullhead and yellow bullhead. Both were collected by minnow traps in isolated ponds with low dissolved-oxygen concentrations $(0.8-1.8 \mathrm{mg} / \mathrm{L}$ at the surface) 10 days after floodwaters receded in August 1989. In addition, young-ofthe-year bullhead (species unknown) guarded by two adults were observed but not collected in August 1988 in the large OBR pond that had been continuously isolated from the river for more than 3 months. Dissolved-oxygen concentrations were relatively low at that time $(1.5 \mathrm{mg} / \mathrm{L}$ at the surface) According to Swift and others (1977), brown bullhead is almost exclusively found in lakes, ponds, and swamps, and yellow bullhead inhabits a great variety of habitats including swamps. These species were restricted to backwater habitats in a lower Mississippi River study (Beckett and Pennington, 1986).

\section{Evidence of Reproduction}

This study was not designed to measure reproductive activity of fishes on flood plains; however, the following observations made during the course of the study help to document the importance of flood plains to fishes. A total of 16 species was collected either in spawning condition or as young-of-the-year in the flood plain. Sampling date, location, and hydrologic conditions for each collection are detailed for spawning fish in appendix II and for young-ofthe-year fish in appendix III. Seven species were collected in spawning condition in drought ponds that had been continuously isolated from the river for 8 to 13 months. However, no spawning beds or nests were observed and no young-of-the-year (except mosquitofish) were collected in drought ponds, possibly because spawning was unsuccessful or delayed, most of the juvenile fish were consumed by predators, or methods of collecting juvenile fish were insufficient. Young-of-the-year of nine species were collected in the flood plain during or shortly after flooding.

Backwaters that were connected to the main channel of the lower Mississippi supported higher densities and different species of larval fishes than the main channel (Beckett and Pennington, 1986). Guillory (1979) reported large numbers of juveniles and adults in spawning condition on inundated flood plains of the lower Mississippi River. Juveniles made up 55 percent of the fishes collected in the flood plain of the Kankakee River, Ill., (Kwak, 1988). Finger and Stewart (1987) caught large numbers of larval and juvenile fishes in seasonally inundated forests in southeastern Missouri. Studies comparing main channel, backwater, and flood-plain populations of larval and 
juvenile fishes would provide valuable additional information about fish reproduction in river-flood-plain systems.

\section{Comparisons of Main Channel and Flood-Plain Species}

This section compares fishes known to inhabit the main channel with those found in the flood plain. Only one method, electrofishing, was used in this study to sample both main channel and flood-plain fishes. Electrofishing results are used in the first part to compare the two habitats with respect to CPUE combined for all species and relative abundance of the most frequently collected species. In the second part, the results of all collection methods are combined, and the overall number of main channel species collected in this and in previous studies is compared to the number of species caught in the flood plain in this study.

\section{Electrofishing Collections}

Forty-two species of fishes were collected by electrofishing in this study (table 5). Thirty-five species were collected in the main channel, 32 in oxbow and open backwater areas, and 24 in inundated flood-plain forests. Although there were 11 more species in the main channel than in the flood plain, the great disparity in sample sizes $(5,266$ in the main channel, 468 in the flood plain) prevents a valid comparison with regard to number of species.

Disparate sample sizes for main channel and flood-plain catches are due not to dissimilar effort but rather to dissimilar CPUE in the two locations (21.9 fish per minute in the main channel, 1.9 in the flood plain). Restricted maneuverability of the electrofishing boat in flooded forests probably contributed to the low CPUE in the flood plain; however, the primary factor was probably that two-thirds of the flood-plain sampling events were conducted at higher river stages than was main channel sampling. As water levels rise and fish spread out into the flood plain, they become less concentrated and more effort is required to sample them. Electrofishing CPUE declined exponentially with increasing river stage (fig. 9). In a regression (significant at the 0.001 level with a standard error of estimate of 0.42), river stage explained 62 percent of the variation in electrofishing CPUE. This exponential decrease in catch can be partially explained by the exponential increase in area available to fish as river stage increases (fig. 10). The area available to fishes during flood stage (20 feet gage datum) is more than eight times the area available at low water (11 feet gage datum). During the mean annual flood (26.7 feet gage datum) the area is almost 60 times that available at low water. Electrofishing catch rates in the main channel of the upper Mississippi River showed an exponential decrease with increasing water levels (Pierce and others, 1985) similar to that shown in figure 9.
Rotenone catches on the Suwannee River flood plain were one or two orders of magnitude greater in sloughs and the main channel during low water than on the inundated flood plain during high water when "fish were scattered over a large are $c^{\prime}$ (Holder, 1971b, p. 53). Comparison of flood-plain collections during flood and drought conditions (tables 3 and 4) also shows an inverse relation between CPUE and water levels. Catch rates during low water conditions were double those during flooded conditions for minnow traps and dip net and were 17 times higher for large wire traps. However, increased movement of fish in sloughs and constricted areas of flood plains may be associated with high water. Kwak (1988) reported that fish movement was positively correlated with river discharge in the flood plain of the Kankakee River, Ill. He measured lateral movement of fishes with nets that blocked off entire passageways in a flood-plain ditch and in a water passage that connected an oxbow pool to the river. Methods used in the current study documented presence of fish in the flood plain but did not measure lateral movement except in some fyke net collections. Fyke nets in this study were placed in sloughs or near constricted areas with wing nets that only partially blocked the passageway. They probably concentrated catches more than other methods in this study but not as much as the traps and block nets used by Kwak.

Comparing abundance of species caught only by electrofishing (table 5), 9 of the 10 most common species collected in the main channel were also commonly collected (relative frequency of 1 percent or more) in the flood plain. Eight of these species, weed shiner, redbreast sunfish, blacktail shiner, brook silverside, bluegill, largemouth bass, redear sunfish, and pugnose minnow, were collected in roughly similar frequencies in both main channel and flood-plain habitats, indicating that they freely exploit the flood plain when it is available. All eight species have been collected on other river flood plains (Holder, 1971b; Bass and Hitt, 1973; Guillory, 1979; Ross and Baker, 1983; Walker and Sniffen, 1985; Finger and Stewart, 1987; and Kwak, 1988). One common main channel species listed in table 5, bannerfin shiner, was also commonly collected in the flood plain but in much lower relative frequencies; it was even less prevalent in quiet oxbow-backwater areas. Examination of flood-plain collections indicates a preference by bannerfin shiner for moving water; all 17 individuals collected in the flood plain were caught at times when some flow was noticeable. Swift and others (1977) found this species in the highest gradient parts of the main river and larger tributaries. The opposite preference was exhibited by bluegill, collected with a relative frequency in oxbow-backwaters roughly 10 times that in the main channel and flood plain. This observation agrees with Beecher and others (1977) who reported that bluegill was the dominant species in an oxbow lake in west Florida and was collected in the oxbow at a catch rate eight times that of the parent river. Only one of the 10 most common main channel species, blackbanded darter, was not common (less 
Table 5 Electrofishing catches in river, backwater, and flood-plain habitats of the Ochlockonee River

[Sampling was conducted from October 1987 through August 1989. Datum of gage is 59.36 feet above mean sea level; $\mathrm{ft} / \mathrm{s}$, feet persecond; <, less than]

\begin{tabular}{|c|c|c|c|}
\hline \multirow[b]{2}{*}{ Species } & \multicolumn{3}{|c|}{ Percentage of catch by species for indicated type of habitat } \\
\hline & $\begin{array}{l}\text { MAIN CHANNEL } \\
\text { with steep, } \\
\text { brushy bank } \\
\text { and velocities } \\
\text { as high as } \\
1.8 \mathrm{ft} / \mathrm{s}^{\prime}\end{array}$ & $\begin{array}{c}\text { OXBOW } \\
\text { AND OPEN } \\
\text { BACKWATER } \\
\text { with no } \\
\text { perceptible } \\
\text { velocity }^{2}\end{array}$ & $\begin{array}{l}\text { INUNDATED } \\
\text { FLOOD PLAIN } \\
\text { with velocities } \\
\text { as high as } \\
0.5 \mathrm{ft} / \mathrm{s}^{3}\end{array}$ \\
\hline Southern brook lamprey & $<0.1$ & & \\
\hline Florida gar & .2 & 1.5 & 0.9 \\
\hline Bowfin & .1 & .1 & .6 \\
\hline $\begin{array}{l}\text { Gizzard shad } \\
\text { Threadfin shad }\end{array}$ & $\begin{array}{l}.5 \\
.3\end{array}$ & 12.9 & $\begin{array}{r}17.5 \\
2.4\end{array}$ \\
\hline Chain pickerel & .1 & .7 & \\
\hline $\begin{array}{l}\text { Common carp } \\
\text { Clear chub }\end{array}$ & $\begin{array}{r}<.1 \\
.5\end{array}$ & & \\
\hline Golden shiner & .1 & .5 & .4 \\
\hline Pugnose minnow & 1.0 & .3 & 2.1 \\
\hline Bannerfin shiner & 13.7 & .9 & 3.6 \\
\hline Taillight shiner & .1 & 5.0 & .6 \\
\hline Coastal shiner & & .1 & .4 \\
\hline Unidentified shiners & .2 & & \\
\hline Weed shiner & 41.3 & 10.1 & 33.8 \\
\hline Blacktail shiner & 12.2 & 6.8 & 7.9 \\
\hline $\begin{array}{l}\text { Lake chubsucker } \\
\text { Spotted sucker }\end{array}$ & .7 & $\begin{array}{r}.1 \\
1.8\end{array}$ & .6 \\
\hline White catfish & .1 & & \\
\hline Yellow bullhead & & .2 & \\
\hline Brown bullhead & $<.1$ & & \\
\hline Channel catfish & .1 & & \\
\hline Spotted bullhead & $<.1$ & & \\
\hline Pirate perch & .3 & .5 & \\
\hline Lined topminnow & $<.1$ & & \\
\hline Mosquitofish & & .1 & .4 \\
\hline Brook silverside & 3.2 & 2.3 & 7.5 \\
\hline White bass & $<.1$ & .1 & \\
\hline Flier & $<.1$ & & .2 \\
\hline Everglades pygmy sunfish & & .1 & \\
\hline Bluespotted sunfish & & .2 & \\
\hline Redbreast sunfish & 13.7 & 18.9 & 10.9 \\
\hline Warmouth & .2 & 2.0 & \\
\hline Bluegill & 2.3 & 22.2 & 2.6 \\
\hline Dollar sunfish & $<.1$ & 2.2 & .2 \\
\hline Redear sunfish & 1.7 & 4.0 & 3.9 \\
\hline Spotted sunfish & .7 & 2.1 & .2 \\
\hline Suwannee bass & .3 & .3 & \\
\hline Largemouth bass & 1.8 & 2.3 & 2.4 \\
\hline Black crappie & 6 & .8 & .2 \\
\hline Swamp darter & & .1 & \\
\hline Gulf darter & .3 & .2 & .2 \\
\hline Blackbanded darter & 3.7 & .5 & .4 \\
\hline Total: & 100.0 & 99.9 & 99.9 \\
\hline Total number of fish: & 5,266 & 873 & 468 \\
\hline Total number of species: & 35 & 32 & 24 \\
\hline Total unit effort in minutes: & 240.8 & 97.1 & 245.6 \\
\hline $\begin{array}{l}\text { Total catch per unit effort } \\
\text { in number of fish per minute: }\end{array}$ & 21.9 & 9.0 & 1.9 \\
\hline
\end{tabular}

${ }^{\mathrm{I}}$ Twenty-four collections made during low to medium river stages (11.3-17.5 feet gage datum).

${ }^{2}$ Four oxbow collections and four backwater collections, all made during low river stages (11.4-13.9 feet gage datum), except for one collection made at medium stage (17.1 feet gage datum). Both areas were just off the main channel and connected to the river at low water.

${ }^{3}$ Eighteen collections made during medium-low to high river stages (14.7-29 feet gage datum). Six of the 18 collections were made at times when there was no perceptible velocity, and the other 12 collections were made at times when velocities were variable. 


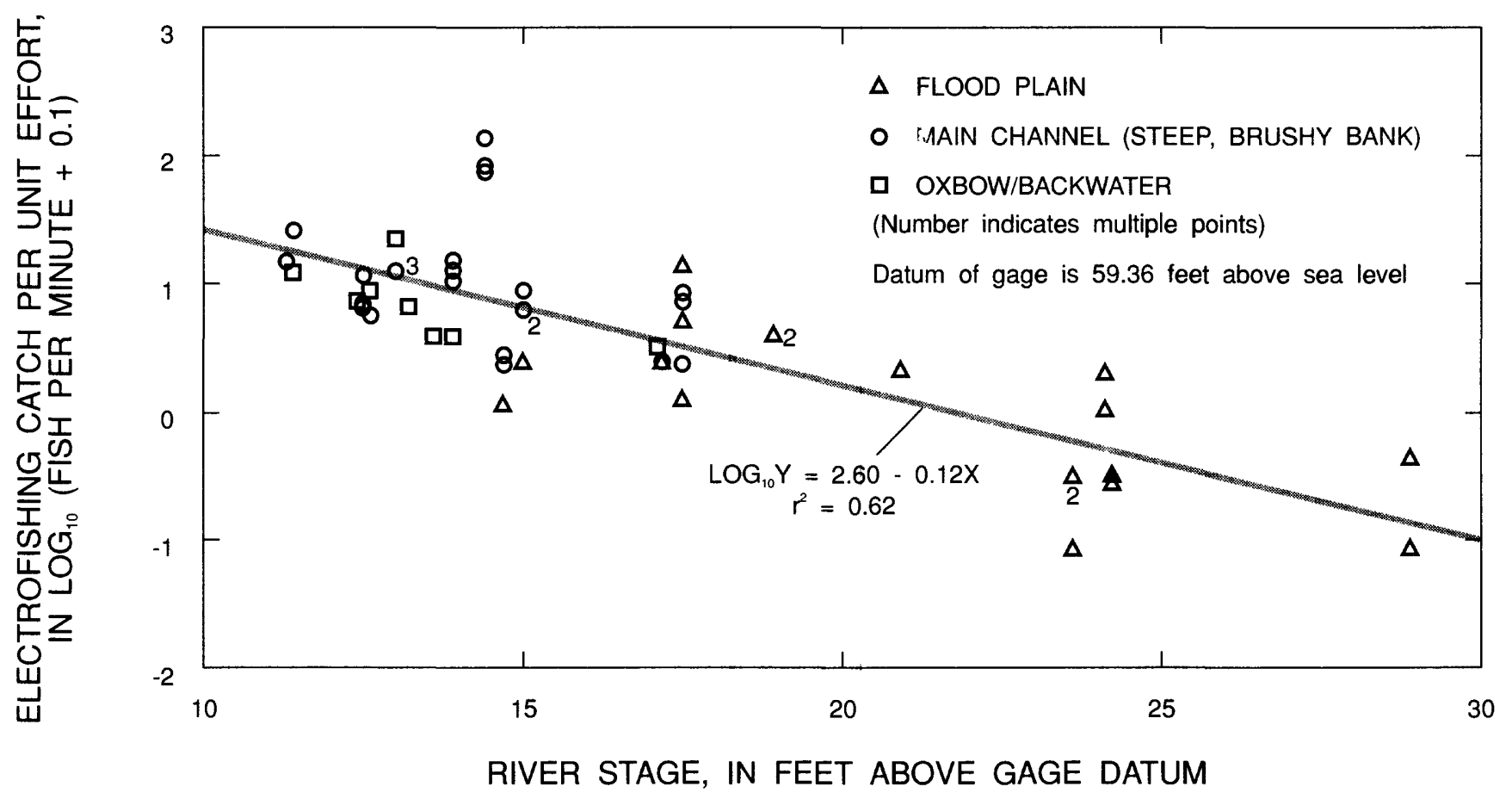

Figure 9. Electrofishing catch per unit effort in relation to river stage at Havana gage.

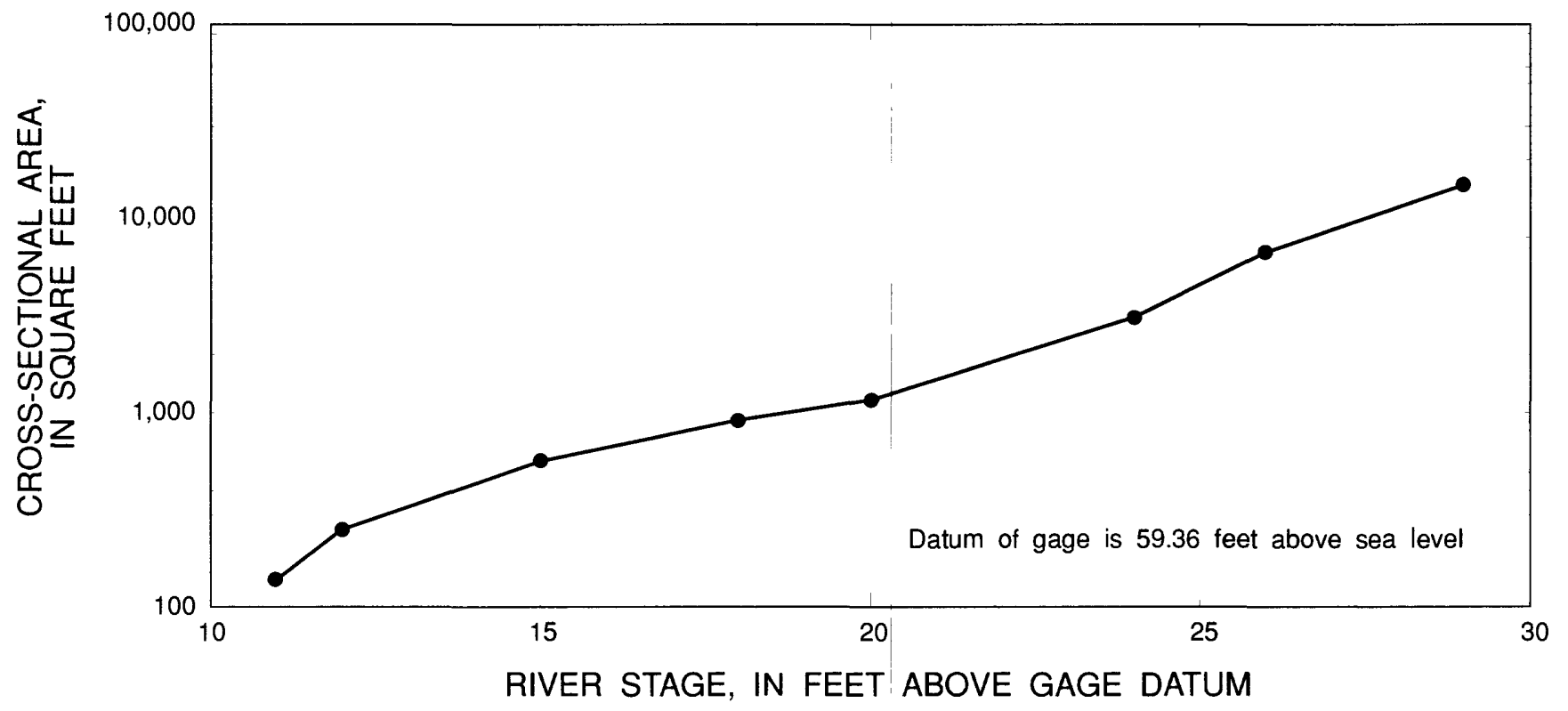

Figure 10. Area available to fishes in relation to river stage at Havana gage. 
than 1 percent relative frequency) in the flood plain. Ross and Baker (1983) also found that this species did not exploit the flood plain of a small creek system in Mississippi.

Although not commonly collected in the main channel, both gizzard shad and threadfin shad were among the most common species collected by electrofishing in the flood plain (table 5). These two species dominated net samples on the lower Mississippi River flood plain (Guillory, 1979). Gizzard shad tend to concentrate in schools, which results in high variability in the catches. In both oxbow-backwater and flood-plain collections, approximately 90 percent of the gizzard shad were caught in a single event. This species may be underrepresented in main channel collections in table 5. In a previous study of the upper Ochlockonee River in Florida, gizzard shad made up 6.9 percent of electrofishing collections in steep, brushy bank areas of the main channel (Dobbins and others, 1987). Gizzard shad was abundant and ubiquitous in a variety of lower Mississippi River habitats according to Beckett and Pennington (1986). In that study, gizzard shad dominated both main channel habitats (with velocities commonly exceeding $3 \mathrm{ft} / \mathrm{s}$ ) and quiet backwater areas.

Quantitative comparisons of main channel and flood-plain fishes were possible because the same method, electrofishing, was used in both habitats. However, these comparisons may inaccurately depict the relative abundance of species in both habitats because of the sampling bias of electrofishing for certain species of fish and the time of year sampling was conducted. Several species infrequently collected by electrofishing in this study were commonly collected with rotenone in late summer at a main channel site close to the Florida-Georgia State line (Keefer and Ober, 1977; Ober and Keefer, 1983). In those studies, 7 species of catfish made up 15 percent of the total number of fishes in a September 1975 rotenone sample, and 5 catfish species made up 20 percent of a September 1982 collection. Pirate perch made up 2 and 4 percent of the 1982 and 1975 collections, respectively.

\section{All Collections Combined}

A comparison based on species presence or absence can be made between known main channel fishes and flood plain collections. Based on electrofishing collections reported in this study (table 5) and in a study by Dobbins and others (1987), and on collections made by Swift and others (1977) using a variety of methods (primarily seines), a total of 42 species is known to inhabit the main channel of the upper Ochlockonee River in Florida. Three-quarters (31) of those species were collected in the flood plain during floods.

Most of the main channel species that were not collected in the flood plain were rare in the main channel as well. However, three species absent in the flood plain, chain pickerel, spotted bullhead, and speckled madtom, wẹre notable in main channel collections in previous studies (Keefer and Ober, 1977; Ober and Keefer, 1983; and
Dobbins and others, 1987). Swift and others (1977) reported that in the Ochlockonee River system, chain pickerel were present in the main channel and larger lakes, whereas redfin pickerel occurred in tributaries, swamps, and smaller lakes. In southeastern Mississippi, speckled madtom was associated with relatively fast currents (Ross and others, 1987), and was rarely collected in the flood plain (Ross and Baker, 1983).

Although many of the species collected in the flood plain in this study are known to inhabit sluggish or standing waters, none are solely restricted to flood-plain habitats. Most centrarchids collected in the isolated flood-plain ponds are common in larger lakes of the region. Some of the drought pond species can even be abundant along the margins of swiftly flowing waters: banded pygmy sunfish can be found in dense vegetation in small creeks with rapid flow (Swift and others, 1977), and bluegill was commonly collected along steep, brushy banks of the main river channel in this study (table 5). However, seven species common in flood-plain collections (flier, banded pygmy sunfish, bluespotted sunfish, least killifish, taillight shiner, and redfin pickerel, common in drought pond collections, and brown bullhead, commonly collected on the inundated flood plain), were rarely collected in the main channel in this or in all previous studies of the upper Ochlockonee River in Florida, in which a variety of methods were used. (Electrofishing collections were reported in table 5 and by Dobbins and others (1987); Swift and others (1977) used mostly seines; Keefer and Ober (1977) and Ober and Keefer (1983) used rotenone to collect samples at a site close to the Florida-Georgia state line.) These species apparently depend on tributary, flood-plain, and backwater habitats for their long-term survival in the upper Ochlockonee River system. Many species, including banded pygmy sunfish, taillight shiner, and flier, that were seined on the flood plain of the lower Mississippi River during a flood, were not commonly occurring species of the main channel (Guillory, 1979). Taillight shiners were commonly collected in an oxbow lake, but were absent in the adjacent main channel of the Escambia River (Beecher and others, 1977). The author speculated that this species could disperse without entering the river because flood-plain lakes and ponds were interconnected during high water.

\section{Importance of Flood-Plain Hydrology to Fishes}

River-flood-plain fishes are dependent upon a fluctuating hydrologic regime for a variety of reasons. The existence of lentic habitats within the flood plain is a result of flood processes; the action of water and transported sediments creates oxbow lakes and backwaters, as well as the levees and terraces that separate flood-plain ponds from the flowing waters of the main channel. These still-water areas sometimes support a biological community distinctly different from that in the flowing waters of the main channel. Beckett and Pennington (1986) reported that 
macroinvertebrates, larval fishes, and fishes of lower Mississippi River backwater areas were dissimilar to those of the main channel. The aquatic macroinvertebrate community of Louisiana cypress-tupelo swamps was characterized by species that were capable of withstanding desiccation during dry periods and a low oxygen environment during wet periods (Sklar, 1985). In this study of the Ochlockonee River, flood-plain ponds during an extended low water period were inhabited by several species of fishes that were not collected in the main channel.

Hydrology is also important to fishes in that flooding is the mechanism by which riverine fishes gain access to flood-plain habitats. The results of this study indicate that in the Ochlockonee River, most main channel fishes take advantage of this increased access to the flood plain during flooding. Additional food sources are made available to fishes when contents of lentic ponds are mixed with floodwaters, and when detritus and terrestrial invertebrates of the flood-plain forest are covered by floods. Several studies of southeastern rivers reviewed by Wharton and others (1981) reported terrestrial invertebrates in the stomachs of fishes on inundated flood plains. According to Welcomme (1979), feeding by many fishes in flood-plain rivers is generally considered to be seasonal, with intensive feeding during floods and fasting during low water periods.

Reproduction in river-flood-plain fishes may be related to hydrologic cycles. Reported spawning times for most Ochlockonee River species approximately coincide with periods of most frequent flooding. Spawning can occur year-round for a number of Ochlockonee River species; however, the most active spawning times reported for nearly all fishes commonly collected in this study were either (1) late winter and spring, (2) spring, or (3) spring and summer (Swift and others, 1977; Ruple and others, 1984; Heins and Rabito, 1986, 1988; and Laerm and Freeman, 1986). Exceptions were chain pickerel and pirate perch, which spawned earlier in winter, and redfin pickerel, which spawned in late fall and winter (Swift and others, 1977). Winter and spring are the most likely times for flooding on the Ochlockonee, and summer floods are common, although of shorter duration than winter-spring floods. Other studies of southeastern rivers have related timing of spawning activities to flooding, and have documented flood-plain habitats as spawning and nursery grounds for certain species (Guillory, 1979; Whartc.. and others, 1981, 1982; Whitehurst, 1981). Spawning of some tropical species is triggered by the onset of flooding and may not occur in years in which floods do not occur (Welcomme, 1979; LoweMcConnell, 1987).

Further research comparing biological communities of flood plains and quiet backwaters to those of main channel habitats, and studying the influence of floods on those communities, would improve the understanding of river-flood-plain interactions. However, because presence or absence of flowing water can influence both composition and productivity of wetland communities (Mitsch and Gosselink, 1986), it is important in flood-plain studies to carefully describe hydrologic conditions at the time of sampling, and how long those conditions existed prior to sampling. This study supports the finding of Beckett and Pennington (1986, p. 18) who stated, "...interpretation of the data requires knowing whether station conditions were lentic or lotic at the time of sampling."

Biological diversity can be higher in systems with pulsing hydrologic cycles than in more hydrologically stable systems, particularly when fluctuating water levels create niches where diverse habitats can develop (Mitsch and Gosselink, 1986). A simple comparison of river and lake fishes in the Ochlockonee basin supports this concept. Nineteen species of fishes were collected over an 8-year period in Lake Jackson, a 1,600-hectare natural lake in the Ochlockonee River basin (Dobbins and Rousseau, 1982); this is less than half the number of species (48) collected in the Ochlockonee River system in this study (appendix I). The fluctuating hydrologic conditions in the Ochlockonee River flood plain, along with the variety of alluvial features and tree communities, probably promote diversity in the fish community. Management strategies that are compatible with the existing hydrologic regime will be most likely to preserve the diverse habitats and biological communities in river-flood-plain systems (Malac and others, 1981).

\section{Importance of Flood-Plain Vegetation to Fishes}

Inundated vegetative structure, both live and dead, provides important substrate, refuge, or food for many invertebrates and fish (Strange and others, 1982; Benke and others, 1985; Harmon and others, 1986; Ploskey, 1986). Stumps, logs, or clumps of vegetation provide shelter for nests of several species of sunfishes and catfishes that were commonly collected in the Ochlockonee River flood plain (Carlander, 1977; Swift and others, 1977; Laerm and Freeman, 1986). A number of species collected in the Ochlockonee River system have adhesive eggs that are deposited in and around vegetation or debris to which they adhere (Laerm and Freeman, 1986). Vegetative cover as protection against predation is an important survival factor for young bluegill (Savino and Stein, 1982). Aggus and Elliott (1975) reported that the amount of flooded vegetation and the duration that it was flooded significantly influenced survival of young largemouth bass during the first 3 months of life.

The importance of leaf litter and plant debris as food at the lowest trophic level in rivers and swamps is well recognized (Cummins, 1974; Mitsch and Gosselink, 1986). The rain of leaves, seeds, pollen, and other organic matter from the trees is thought to be the primary source of food in river-flood-plain systems (Welcomme, 1979). The importance of leaves as food for aquatic organisms probably lies in providing an energy source for microbes, which together with the leaves upon which they are growing, serve as food for many invertebrates (Kaushik and Hynes, 1971). The variety of tree species occurring in the different zones of 
the Ochlockonee River flood plain (table 2) produces leaves of varying texture and nutrient composition. Because decomposition rates and microbial activity are highly species dependent, diversity of forest types may play an important role in supporting diverse invertebrate and fish communities (Kaushik and Hynes, 1971; Elder and Cairns, 1982). Leaves that "decay fastest tend to be eaten first, so that through fall, winter and spring, which are the main growing periods for a large number of stream animals, there is a steady and maintained supply of protein-rich food" (Kaushik and Hynes, 1971, p. 504). Variety in hydrologic conditions within the flood plain may also contribute to this steady release of detrital nutrients because studies have shown that decomposition in the frequently flooded cypress-tupelo zone proceeds faster than in the drier high terrace or riverbank levee community (Brinson, 1977; Elder and Cairns, 1982).

Crayfish are detritus feeders that commonly inhabit many southeastern river flood plains (Wharton and others, 1981; Lambou, 1990). Holder (1971a) reported that crayfish were the dominant benthic invertebrate by weight in flood-plain collections on the Suwannee River in Georgia. In this study of the Ochlockonee River flood plain, nearly 300 crayfish were caught, primarily in minnow traps. Lambou (1990) considers crayfish to be a direct trophic link between detritus and larger fish. In Creeping Swamp, N.C., crayfish constituted 61 percent of the total weight of fish stomach contents (Walker and Sniffen, 1985). Crayfish can be a principal food for warmouth and largemouth bass, and they are sometimes an important dietary item of many other species found in the Ochlockonee River flood plain (Carlander, 1969, 1977; Wharton and others, 1981; Walker and Sniffen, 1985; Lambou, 1990).

Most fishes eat and digest both plant and animal material in early life, regardless of adult dietary preferences that develop later (Lagler, 1956). Invertebrates and smaller fishes are the primary diet of most Ochlockonee River fishes as adults; however, a few species have been known to consume considerable amounts of plant material (Carlander, 1969, 1977; Laerm and Freeman, 1986). Detritus was the dominant food item in the dry season for weed shiner, blacktail shiner, pugnose minnow, and mosquitofish in southwestern Louisiana (Felley and Felley, 1987) and is reported to be a significant dietary item of spotted sucker, spotted sunfish (Laerm and Freeman, 1986), and bluegill (Felley and Felley, 1987). The channel catfish has an extremely varied diet which includes detritus and other plant material (Laerm and Freeman, 1986). This species consumed large numbers of elm seeds in a Des Moines River study (Bailey and Harrison, 1945); however, in general, fruit- and seed-eating fishes appear to be poorly represented outside of Souin America (Goulding, 1980). Diet studies of fishes inhabiting flood plains might identify more precisely the flood-plain plant species used directly by fishes. However, for most Florida fishes, plant and detrital material, and the bacteria and fungi that feed on it, are probably ac imnortant as a source of food for invertebrate prey than they are as a direct source of fish food. Flood-plain invertebrate studies that identify the litter substrates upon which they depend would be very useful, particularly if those invertebrates were shown to be eaten by fishes during floods.

\section{SUMMARY AND CONCLUSIONS}

Hydrologic conditions were measured, and vegetation and fishes were sampled from September 1987 through August 1989 in the Ochlockonee River flood plain of northwest Florida. Flood-plain habitats were diverse with respect to hydrologic conditions and vegetation. Three-quarters of the fish species known to occur in the main channel were collected in the flood plain. The study period included a drought during which flood-plain ponds were isolated from the river for 10 to 14 months. Thirteen species found in drought ponds had survived low dissolved oxygen concentrations the preceding fall. Seven common flood-plain species that were rare or absent in the main channel apparently depend on flood-plain, backwater, and tributary habitats for their survival in this river system. Principal conclusions resulting from the study of hydrology, vegetation, and fishes of the Ochlockonee River flood plain are as follows:

- Alluvial flood-plain processes such as erosion and sediment deposition create topographic relief on the flood-plain surface that allows diverse habitats to develop. Riverbank levees and terraces serve as berms during low and medium river stages, separating still-water habitats in ponds and depressions from the flowing waters of the main channel. Depressions hold water after floods recede and after heavy local rains, but are normally dry part of each year during periods of low water. Permanent ponds and oxbow lakes of various sizes are common throughout the flood plain.

- The annual flood season of the Ochlockonee River typically occurs in January, February, March, and April. Summer floods are common but usually of shorter duration than winter-spring floods. Typical range in stage is 16 feet from the low to the high for the year. The study period included two flood periods with an intervening drought that was one of the five longest droughts in the 59-year period of record. During this drought, ponds and other flood-plain features at the study sites were isolated from the river continuously for 10 to 14 months.

- The Ochlockonee River flood plain contains a combination of lentic (still water) and lotic (flowing water) habitats that are sometimes isolated and sometimes connected. During large floods, all areas of the flood plain are lotic, although velocities are usually much lower in the flood plain than in the main channel. The amount of time 
that different water bodies in the flood-plain were lotic rather than lentic was quite variable.

- Tree communities were distinctly different in each topographic zone, reflecting the varied hydrologic conditions existing within the flood plain. High terraces supported a mixture of canopy species including spruce pine, sweetgum, live oak, and water oak, and usually were flooded 2 to 3 weeks a year. Low terraces, dominated by a canopy of swamp laurel oak, normally were flooded a total of 2 to 4 months of the year (not necessarily consecutive). The dominant canopy species in depressions was Ogeechee tupelo, with bald-cypress the most common associate. Depressions were typically flooded by the river a total of 3 to 5 months of the year, but water was commonly trapped in these areas long after floods receded.

- The amount of vegetative structure in three topographic zones was measured before and after flooding. Dead vegetative structure included leaf litter, branches, limbs, and rotten logs, which are largely derived from the canopy trees. Live structure included tree trunks, smaller woody plants, and herbaceous plants. Live and dead vegetative structure in the flood plain, and the amount of time it was flooded, varied with topographic zone and season. High terraces had more live vegetation per area (especially in the ground cover) but less debris or dead vegetation than either of the other two zones. Live vegetation in the ground cover was sparse on the low terraces but the greatest amount of debris and dead vegetation occurred in this zone. Cypress-tupelo zones had very sparse ground cover, and had the lowest amount of total vegetative structure (live and dead) of any of the zones, but were flooded (and thus available to fishes) for longer periods of time than were the high and low terraces. The amount of dead vegetative structure decreased after flooding in all three zones, indicating that much of the accumulated debris on the flood plain may have been washed off during floods. Among the live vegetation, redtop panicum, with its large clumps of dead stalks and leaves that persist through the winter-spring flood season, provided one of the most likely sources of protective cover for fishes.

- A total of 8,225 fish belonging to 15 families and 48 species were collected by five different sampling methods in flood-plain, backwater, and main channel habitats. Eighty-one percent of the fish belonged to two families, minnows and carps (Cyprinidae) and sunfishes (Centrarchidae).

- Thirty-seven species of fish were collected in the flood plain during flood conditions. Based on combined catches from five different sampling methods, the most frequently collected species in the flood plain during floods (in order from most to least common) were weed shiner, redbreast sunfish, brown bullhead, bluegill, gizzard shad, mosquitofish, and redear sunfish. All seven of these species have been collected on inundated flood plains of other rivers in the eastern United States. Use of several different nethods was necessary to effectively sample the flood plain under fluctuating water levels and each method was biased towards certain species of fish. Electrofishing and fyke net collections yielded the greatest number of species and individuals; however, minnow traps and dip nets collected five additional species not caught by the former two methods.

- During the drought, thirteen species were observed or collected with minnow traps, large wire traps, or dip nets in small flood-plain ponds which had been isolated from the river continuously for 8 to 13 months. These species survived surface dissolved-oxygen concentrations as low as 0.6 to $0.8 \mathrm{mg} / \mathrm{L}$ in the preceding fall. Based on combined catches from all three methods, flier, pirate perch, mosquitofish, and warmouth were the most common species collected in isolated ponds during the drought. The largest pond had the greatest species richness.

- Forty-two species of fish were collected by boat electrofishing in main channel, backwater, and flood-plain habitats during the 2-year study. Comparing abundance of species caught only by electrofishing, nine of the ten most common species collected in the main channel were also commonly collected (relative frequency of 1 percent or more) in the flood plain. Electrofishing catch per unit effort was much lower in the flood plain than in the main channel, probably because rising water levels allowed fish to spread out into the flood plain. Amount of habitat area available to fish increased exponentially with increasing river stage.

- A total of 42 species are known to inhabit the main channel of the upper Ochlockonee River in Florida, based on investigations made using a variety of methods. In this study, three-quarters of those species were collected in the flood plain during floods.

- Flood plains, backwaters, and tributaries appeared to be the primary or exclusive habitat for seven species that were rare or absent in main channel collections in this study and in previous studies (flier, banded pygmy sunfish, bluespotted sunfish, least killifish, taillight shiner, redfin pickerel, and brown bullhead).

- River-flood-plain fish communities are dependent upon a fluctuating hydrologic regime. Flood processes create oxbow lakes and backwaters, as well as the levees and terraces that separate flood-plain ponds from the main 
channel. Lentic flood-plain habitats sometimes support biological communities distinctly different from those of flowing waters of the main channel. Isolated ponds in the Ochlockonee River flood plain were inhabited by several species of fishes not collected in the main channel. Flooding is the mechanism by which riverine fishes gain access to flood-plain habitats. Results of this study indicate that most of the main channel fishes of the Ochlockonee River take advantage of this increased access to the flood plain. Additional food sources are made available to fishes when contents of lentic ponds are mixed with flood waters, and when detritus and terrestrial invertebrates of the flood-plain forest are covered by floods. Reproduction may be related to hydrologic cycles. Reported spawning times for most Ochlockonee River species approximately coincide with periods of most frequent flooding.

- Studies documenting the use of vegetation by fish species that inhabit the Ochlockonee River flood plain were examined. A number of fish species commonly collected in the flood plain are known to use vegetative structure as shelter for nests and sites for deposition of adhesive eggs. Vegetative cover as protection against predation has been shown to be an important survival factor for young fishes. Decomposing leaf litter and plant debris serve as food for invertebrates and fishes. Studies showing that litter decomposition rates vary with species and hydrologic conditions indicate that the diversity of habitats on the Ochlockonee River flood plain may be an important factor in maintaining a steady supply of detrital nutrients for invertebrates. Crayfish, which commonly were collected in this study, are primarily detritus feeders and are known to be an important food for many Ochlockonee River fishes. Detritus has also been reported to be a direct, and sometimes primary, source of food for some Ochlockonee River fishes.

- Research needs identified in this study included: (1) comparisons of the biological communities of flood plains and quiet backwaters to those of main channel habitats, (2) research on effects of flooding on biological communities in lotic and lentic habitats of river flood plains, (3) comparisons of main channel, backwater, and flood-plain populations of larval and juvenile fishes, (4) flood-plain invertebrate studies that identify the litter substrates upon which they depend, (5) diet studies identifying the flood-plain plants and invertebrates eaten by fishes during floods, and (6) research on geographic variations of dissolved oxygen tolerance levels of fishes. Descriptions of hydrologic conditions at the time of sampling, and the period of time those conditions existed prior to sampling, are important considerations in all flood-plain studies.
- The fluctuating hydrologic conditions of the river-flood-plain system, along with the variety of alluvial features and tree communities, probably promote diversity in the fish community. Management strategies that are compatible with the existing hydrologic regine will be most likely to preserve the diverse habitats and biological communities of the Ochlockonee River and flood plain.

\section{SELECTED REFERENCES}

Aggus, L.R., and Elliott, G.V., 1975, Effects of cover and food on year-class strength of largemouth bass, in Stroud, R.H., and Clepper, Henry, eds., Black bass biology and management: Washington, D.C., Sport Fishing Institute, p. 317-322.

Bailey, R.M., and Harrison, H.M., Jr., 1945, Food habits of the southern channel catfish (Ictalurus lacustris punctatus) in the Des Moines River, Iowa: Transactions of the American Fisheries Society, v. 75, p. 110-138.

Bass, D.G., Jr., 1983, Rivers of Florida and their fishes: Florida Game and Fresh Water Fish Commission, 397 p.

Bass, D.G., Jr., and Hitt, V.G., 1973, Sport fishery ecology of the Suwannee and Santa Fe Rivers, Florida: Lake City, Florida Game and Fresh Water Fish Commission, 187 p.

Beckett, D.C., and Pennington, C.H., 1986, Water quality, macro-invertebrates, larval fishes, and fishes of the lower Mississippi River--A synthesis: Vicksburg, Miss., U.S. Army Waterways Experiment Station Technical Report E-86-12, $136 \mathrm{p}$.

Bedinger, M.S., 1981, Hydrology of bottomland hardwood forests of the Mississippi embayment, in Clark, J.R., and Benforado, J., eds., Wetlands of bottomland hardwood forests: Proceedings of a Workshop on bottomland hardwood forest wetlands of the Southeastern United States held at Lake Lanier, Georgia: New York, Elsevier Scientific Publication Co., p. 161-176.

Beecher, H.A., Hixson, W.C., and Hopkins, T.S., 1977, Fishes of a Florida oxbow lake and its parent river: Florida Scientist, v. 40 , no. 2 , p. $140-148$.

Benke, A.C., Henry, R.L., III, Gillespie, D.M., and Hunter, R.J., 1985, Importance of snag habitat for animal production in southeastern streams: Fisheries, v. 10, no. 5, p. 8-13.

Berra, T.M., 1989, The significance of William Bartram (1739-1823) to North American ichthyology: American Midland Naturalist, v. 122, p. 214-227.

Brinson, M.M., 1977, Decomposition and nutrient exchange of litter in an alluvial swamp forest: Ecology, v. 58, p. 601-609.

Brinson, M.M., Bradshaw, H.D., Holmes, R.N., and Elkins, J.B., Jr., 1980, Litterfall, stemflow, and throughfall nutrient fluxes in an alluvial swamp forest: Ecology, v. 61(4), p. 827-835.

Carlander, K.D., 1969, Handbook of freshwater fishery biology; Volume one: Ames, The Iowa State University Press, 752 p.

---- 1977, Handbook of freshwater fishery biology; Volume two: Ames, The Iowa State University Press, 431 p.

Clark, W.Z., Jr., and Zisa, A.C., 1976, Physiographic map of Georgia: Atlanta, Georgia Department of Natural Resources, scale $1: 2,000,000,1$ sheet. 
Clewell, A.F., 1985, Guide to the vascular plants of the Florida panhandle: Tallahassee, University Presses of Florida, $605 \mathrm{p}$.

Cooke, C.W., 1939, Scenery of Florida interpreted by a geologist: Florida Geological Survey Bulletin 17, 118 p.

Cummins, K.W., 1974, Structure and function of stream ecosystems: Bioscience, v. 24, no. 11, p. 631-641.

Dahlberg, M.D., and Scott, D.C., 1971, The freshwater fishes of Georgia: Bulletin of the Georgia Academy of Science, v. 29, p. 1-64.

Davis, J.C., 1975, Minimal dissolved oxygen requirements of aquatic life with emphasis on Canadian species: A review: Journal of the Fisheries Research Board of Canada, v. 32(12), p. 2295-2332.

Dierberg, F.E., and Brezonik, P.L., 1984, Water chemistry of a Florida cypress dome, in Ewel, K.C., and Odum, H.T., eds., Cypress swamps: Gainesville, University Presses of Florida, p. 34-50.

Dobbins, D.A., Long, E.A., Nordhaus, J.J., Lubinski, B.R., 1987, Ochlockonee River watershed studies, final report: Florida Game and Fresh Water Fish Commission, 99 p.

Dobbins, D.A., and Rousseau, R.W., 1982, Lakes Talquin and Jackson investigations, completion report: Florida Game and Freshwater Fish Commission, $174 \mathrm{p}$.

Douglas, N.H., 1974, Freshwater fishes of Louisiana: Louisiana Wildlife and Fisheries Commission, 443 p.

Elder, J.F., and Cairns, D.J., 1982, Production and decomposition of forest litter fall on the Apalachicola River flood plain: U.S. Geological Survey Water-Supply Paper 2196, chap. B, 42 p.

Felley, J.D., and Felley, S.M., 1987, Relationships between habitat selection by individuals of a species and patterns of habitat segregation among species: Fishes of the Calcasieu drainage, in Matthews, W.J., and Heins, D.C., eds., Community and evolutionary ecology of North American stream fishes: Norman, University of Oklahoma Press, p. 61-68.

Finger, T.R., and Stewart, E.M., 1987, Responses of fishes to flooding regime in lowland hardwood wetlands, in Matthews, W.J., and Heins, D.C., eds., Community and evolutionary ecology of North American stream fishes: Norman, University of Oklahoma Press, p. 86-92.

Florida Department of Environmental Regulation, 1987, An investigation of the water quality of the Ochlockonee River: $287 \mathrm{p}$.

Foose, D.W., 1981, Drainage areas of selected surface-water sites in Florida: U.S. Geological Survey Open-File Report 81-482, $83 \mathrm{p}$.

Friedemann, Mark, and Hand. Joe, 1989, Typical water quality values for Florida's lakes, streams and estuaries: Tallahassee, Florida Department of Environmental Regulation, $32 \mathrm{p}$.

Godfrey, R.K., 1988, Trees, shrubs, and woody vines of northern Florida and adjacent Georgia and Alabama: Athens, The University of Georgia Press, $734 \mathrm{p}$.

Godfrey, R.K., and Wooten, J.W., 1979, Aquatic and wetland plants of southeastern United States: Athens, The University of Georgia Press, $712 \mathrm{p}$.

-.-- 1981, Aquatic and wetland plants of southeastern United States: Athens, The University of Georgia Press, 933 p.

Goulding, Michael, 1980, The fishes and the forest: Explorations in Amazonian natural history: Berkeley, University of California Press, 280 p.
Greeson, P.E., Clark, J.R., Clark, J.E., eds., 1979, Wetlands functions and values: The state of our understanding: Proceedings of the National Symposium on Wetlands held in Lake Buena Vista, Florida: Minneapolis, Minn., American Water Resources Association, 674 p.

Guillory, Vincent, 1979, Utilization of an inundated floodplain by Mississippi River fishes: Florida Scientist, v. 42, no. 4, p. 222-228.

Hall, H.D., and Lambou, V.W., 1990, The ecological significance to fisheries of bottomland hardwood systems: Values, detrimental impacts, and assessment: The report of the fisheries workgroup, in Gosselink, J.G., Lee, L.C., and Muir, T.A., eds., Ecological processes and cumulative impacts: Illustrated by bottomland hardwood wetland ecosystems: Chelsea, Mich., Lewis Publishers, p. 481-531.

Halyk, L.C., and Balon, E.K., 1983, Structure and ecological production of the fish taxocene of a small floodplain system: Canadian Journal of Zoology, v. 61, no. 11, p. 2446-2464.

Hampson, P.S., 1989, Dissolved-oxygen concentrations in a central Florida wetlands stream, in Fisk, D.W., ed., Proceedings of the Symposium on Wetlands: Concerns and successes, held in Tampa, Fla.: Bethesda, Md., American Water Resources Association, p. 149-159.

Harmon, M.E., Franklin, J.F., Swanson, F.J., Sollins, P., Gregory, S.V., Lattin, J.D., Anderson, N.H., Cline, S.P., Aumen, N.G., Sedell, J.R., Lienkaemper, G.W., Cromack, K., Jr., and Cummins, K.W., 1986, Ecology of coarse woody debris in temperate ecosystems, in MacFadyen, A., and Ford, E.D., eds., Advances in Ecological Research, v. 15: London, Academic Press, Harcourt Brace Jovanovich, p. 133-302.

Harper, F., 1943, Travels in Georgia and Florida, 1773-74: A report of Dr. Fothergill: William Bartram: Transactions of the American Philosophical Society, v. 33(2): 121-242.

He, Xi, and Lodge, D.M., 1990, Using minnow traps to estimate fish population size: The importance of spatial distribution and relative species abundance: Hydrobiologia, v. 190, p. 9-14.

Heath, R.C., and Conover, C.S., 1981, Hydrologic almanac of Florida: U.S. Geological Survey Open-File Report 81-1107, $239 \mathrm{p}$.

Heins, D.C., and Rabito, F.G., Jr., 1986, Spawning performance in North American minnows: Direct evidence of the occurrence of multiple clutches in the genus Notropis: Journal of Fish Biology, v. 28, p. 343-357.

---- 1988, Reproductive traits in populations of the weed shiner, Notropis texanus, from the Gulf Coastal Plain: The Southwestern Naturalist, v. 33(2), p. 147-156.

Holder, D.R., 1971a, Study VII, Job 1: Invertebrate studies in warmwater streams: Statewide Fisheries Investigation F-21-2, Georgia Department of Natural Resources, 17 p.

-.--- 1971b, Study XVI, Job 2: Population studies--streams: Statewide Fisheries Investigations F-21-2, Georgia Department of Natural Resources, 66 p.

Holder, D.R., and Gasaway, R.D., 1974, Study VI, Job 2: Study of fish movements from tributary streams into the Suwannee River: Statewide Fisheries Investigations F-21-5, Georgia Department of Natural Resources, $70 \mathrm{p}$.

Jones, J.R.E., 1964, Fish and river pollution: Washington, D.C., Butterworth \& Co. Ltd., 203 p. 
Kaushik, N.K., and Hynes, H.B.N., 1968, Experimental study on the role of autumn-shed leaves in aquatic environments: Journal of Ecology, v. 56, p. 229-243.

---- 1971, The fate of the dead leaves that fall into streams: Archiv fur Hydrobiologie, v. 68, p. 465-515.

Keefer, L.C., and Ober, R.D., 1977, A survey of the Ochlockonee River and its fishery: Georgia Department of Natural Resources, $47 \mathrm{p}$.

Kramer, D.L., Lindsey, C.C., Moodie, G.E.E., and Stevens, E.D., 1978, The fishes and the aquatic environment of the central Amazon basin, with particular reference to respiratory patterns: Canadian Journal of Zoology, v. 56, p. 717-729.

Kuehne, R.A., and Barbour, R.W., 1983, The American darters: The University Press of Kentucky, $177 \mathrm{p}$.

Kwak, T.J., 1988, Lateral movement and use of floodplain habitat by fishes of the Kankakee River, Illinois: The American Midland Naturalist, v. 102, no. 2, p. 241-249.

Laerm, Joshua, and Freeman, B.J., 1986, Fishes of the Okefenokee Swamp: Athens, The University of Georgia Press, $118 \mathrm{p}$.

Lagler, K.F., 1956, Freshwater fishery biology (2d ed.): Dubuque, Iowa, Wm. C. Brown Company, 421 p.

Lambou, V.W., 1959, Fish populations of backwater lakes in Louisiana: Transactions of the American Fisheries Society, v. 88 , no. 1 , p. $7-15$.

---- 1990, Importance of bottomland hardwood forest zones to fishes and fisheries: The Atchafalaya basin, a case history, in Gosselink, J.G., Lee, L.C., and Muir, T.A., eds., Ecological processes and cumulative impacts: Illustrated by bottomland hardwood wetland ecosystems: Chelsea, Mich., Lewis Publishers, p. 125-193.

Larson, J.S., Bedinger, M.S., Bryan, C.F., Brown, S., Huffman, R.T., Miller, E.L., Rhodes, D.G., and Touchet, B.A., 1981, Transition from wetlands to uplands in southeastern bottomland hardwood forests, in Clark, J.R., and Benforado, J., eds., Wetlands of bottomland hardwood forests: Proceedings of a workshop on bottomland hardwood forest wetlands of the Southeastern United States held at Lake Lanier, Georgia: New York, Elsevier Scientific Publication Co., p. 225-273.

Lee, D.S., Gilbert, C.R., Hocutt, C.H., Jenkins, R.E., McAllister, D.E., and Stauffer, J.R., Jr., 1980, Atlas of North American freshwater fishes: North Carolina Biological Survey, Publication No. 1980-12, 854 p.

Leitman, H.M., Sohm, J.E., and Franklin, M.A., 1983, Wetland hydrology and tree distribution of the Apalachicola River flood plain, Florida: U.S. Geological Survey Water-Supply Paper 2196-A, 52 p.

Leopold, L.B., Wolman, M.G., and Miller, J.P., 1964, Fluvial processes in geomorphology: San Francisco, W.H. Freeman and Company, $522 \mathrm{p}$.

Lowe-McConnell, R.H., 1987, Ecological studies in tropical fish communities: Cambridge, Mass., Cambridge University Press, $382 \mathrm{p}$.

Malac, B.F., Combs, P.G., Holloway, L.F., Langdon, G.G., Mitsch, W.J., Todd, Robert, and Riekerk, Hans, 1981, Management of southeastern bottomland hardwood forests: Opportunities and constraints, in Clark, J.R., and Benforado, J., eds., Wetlands of bottomland hardwood forests: Proceedings of a workshop on bottomland hardwood forest wetlands of the Southeastern United States, Lake Lanier, Ga., June 1-5, 1980: Amsterdam, Elsevier Scientific Publishing Company, p. 335-357.
Milleson, J.F., 1976, Environmental responses to marshland reflooding in the Kissimmee River basin: Central and Southern Florida Flood Control District Technical Publication No. 76-3, 39 p.

Mitsch, W.J., and Gosselink, J.G., 1986, Wetlands: New York, Van Nostrand Reinhold, $539 \mathrm{p}$.

Moore, W.G., 1942, Field studies on the oxygen requirements of certain fresh-water fishes: Ecology, v. 23, no. 3, p. 319-329.

Mueller-Dombois, Dieter, and Ellenberg, Heinz, 1974, Aims and methods of vegetation ecology: New York, John Wiley and Sons, $547 \mathrm{p}$.

Ober, R.D., and Keefer, L.C., 1983, An evaluation of the current fish population structure in the Ochlockonee River: Georgia Department of Natural Resources, $18 \mathrm{p}$.

Pardue, G.B., and Huish, M.T., 1981, An evaluation of methods for collecting fishes in swamp streams, in Krumholz, L.A., ed., The warmwater streams symposium held in Knoxville, Tenn.: Lawrence, Kans., American Fisheries Society, Southern Division, p. 282-290.

Parrish, P.R., Yerger, R.W., 1974, Ochlockonee River fishes: Salinity- temperature effects: Florida Scientist, v. 36, no. 2-4, p. 179-186.

Pascale, C.A., and Wagner, J.R., 1982, Water resources of the Ochlockonee River area, northwest Florida: U.S. Geological Survey Open-File Report 81-1121, 114 p.

Petit, G.D., 1973, Effects of dissolved oxygen on survival and behavior of selected fishes of western Lake Erie: Bulletin of the Ohio Biological Survey, v. 4, no. 4, p. 1-76.

Pierce, R.B., Coble, D.W., and Corley, S.D., 1985, Influence of river stage on shoreline electrofishing catches in the upper Mississippi River, in Transactions of the American Fisheries Society, v. 114, p. 857-860.

Ploskey, G.R., 1986, Management of the physical and chemical environment; Effects of water-level changes on reservoir ecosystems with implications for fisheries management, in Reservoir Fisheries Management: Strategies for the 80's: Bethesda, Md., American Fisheries Society, Southern Division, p. 86-97.

Puri, H.S., and Vernon, R.O., 1964, Summary of the geology of Florida and a guidebook to the classic exposures: Tallahassee, Florida Geological Survey Special Publication no. 5 , revised, $312 \mathrm{p}$.

Robins, C.R., Bailey, R.M., Bond, C.E., Brooker, J.R., Lachner, E.A., Lea, R.N., and Scott, W.B., 1980, A list of common and scientific names of fishes from the United States and Canada (4th ed.): Bethesda, Md., American Fisheries Society Special Publication No. 12, 174 p.

Ross, S.T., and Baker, J.A., 1983, The response of fishes to periodic spring floods in a southeastern stream: The American Midland Naturalist, v. 109, no. 1, 14 p.

Ross, S.T., and Baker, J.A., and Clark, K.E., 1987, Microhabitat partitioning of southeastern stream fishes: Temporal and spatial predictability, in Matthews, W.J., and Heins, D.C., eds., Community and evolutionary ecology of North American Stream Fishes: Norman, University of Oklahoma Press, p. 42-51.

Ruple, D.L., McMichael, R.H., Jr., and Baker, J.A., 1984, Life history of the gulf darter, Etheostoma swaini (Pisces: Percidae): Environmental Biology of Fishes, v. 11, no. 2, p 121-130. 
Savino, J.F., and Stein, R.A., 1982, Predator-prey interaction between largemouth bass and bluegills as influenced by simulated, submersed vegetation: Transactions of the American Fisheries Society, v. 111, no. 3, p. 255-266.

Seaburg, K.G., and Moyle, J.B., 1964, Feeding habits, digestive rates, and growth of some Minnesota warmwater fishes: Transactions of the American Fisheries Society, v. 93, no. 3, p. 269-285.

Sklar, F.H., 1985, Seasonality and community structure of the backswamp invertebrates in a Louisiana cypress-tupelo wetland: Wetlands, v. 5, p. 69-86.

Stevenson, H.M., 1976, Vertebrates of Florida: Identification and distribution: Gainesville, University Presses of Florida, $607 \mathrm{p}$.

Strange, R.J., Kittrell, W.B., and Broadbent, T.D., 1982, Effects of seeding reservoir fluctuation zones on young-of-the-year black bass and associated species: North American Journal of Fisheries Management, v. 2, no. 4., p. 307-315.

Swift, C.C., Gilbert, C.R., Bortone, S.A., Burgess, G.H., and Yerger, R.W., 1986, Zoogeography of the freshwater fishes of the southeastern United States: Savannah River to Lake Pontchartrain, in Hocutt, C.H., and Wiley, E.O., eds., The zoogeography of North American freshwater fishes: New York, John Wiley, chap. 7, p. 213-265.

Swift, C.C., Yerger, R.W., and Parrish, P.R., 1977, Distribution and natural history of the fresh and brackish water fishes of the Ochlockonee River, Florida and Georgia: Tallahassee, Fla., Tall Timbers Research Station Bulletin, no. 20,111 p.

U.S. Army Corps of Engineers, 1985, Florida-Georgia stream mileage tables with drainage areas: Mobile, Ala., U.S. Army Engineer District, $233 \mathrm{p}$.

U.S. Geological Survey, 1931-89, Water resources data for Florida: U.S. Geological Survey Water-Data Reports (published annually).

Walker, M.D., and Sniffen, Robert, 1985, Fish utilization of an inundated swamp-stream floodplain: Corvallis, Oreg., U.S. Environmental Protection Agency, EPA-600/3-85-046, 72 p.

Warren, C.E., 1971, Biology and water pollution control: Philadelphia, W.B. Saunders Company, 434 p.

Wegener, W.L., Holcomb, D.E., and Williams, V.P., 1973, Sampling shallow water fish populations using the Wegener ring, in Proceedings of the twenty-seventh annual conference:
Southeastern Association of Game and Fish Commissioners, Hot Springs, Ark., p. 663-673.

Welcomme, R.L., 1979, Fisheries ecology of floodplain rivers: New York, Longman, Inc., 317 p.

Wells, M.M., 1915, Reactions and resistance of fishes in their natural environment to acidity, alkalinity and neutrality: Wood's Hole, Mass., Biology Bulletin, 29, p. 221-257.

Wharton, C.H., 1978, The natural environments of Georgia: Georgia Department of Natural Resources, $227 \mathrm{p}$.

Wharton, C.H., Kitchens, W.M., Pendleton, E.C., and Sipe, T.W., 1982, The ecology of bottomland hardwood swamps of the Southeast: A community profile: U.S. Fish and Wildlife Service, FWS/OBS-81/37, 133 p.

Wharton, C.H., Lambou, V.W., Newsom, J., Winger, P.V., Gaddy, L.L., and Mancke, R., 1981, The fauna of bottomland hardwoods in Southeastern United States, in Clark, J.R., and Benforado, J., eds., Wetlands of bottomland hardwood forests: Proceedings of a workshop on bottomland hardwood forest wetlands of the Southeastern United States held at Lake Lanier, Georgia: New York, Elsevier Scientific Publication Co., p. 87-160.

Wharton, C.H., Odum, H.T., Ewel, K., Duever, M., Lugo, A., Boyt, R., Bartholomew, J., DeBellevue, E., Brown, S., Brown, M., and Duever, L., 1977, Forested wetlands of Florida--their management and use: Gainesville, University of Florida, $348 \mathrm{p}$.

Whitehurst, D.K., 1981, Seasonal movements of fishes in an eastern North Carolina swamp stream, in Krumholz, L.A., ed., The warmwater streams symposium held in Knoxville, Tenn.: Lawrence, Kans., American Fisheries Society, Southern Division, p. 182-190.

Williamson, K.L., and Nelson, P.C., 1985, Habitat suitability index models and instream flow suitability curves: Gizzard shad: U,S. Fish and Wildlife Service Biological Report 82(10.112), $33 \mathrm{p}$.

Wood, D.A., 1988, Official lists of endangered and potentially endangered fauna and flora in Florida: Florida Game and Fresh Water Fish Commission, $19 \mathrm{p}$.

Wyatt, Herbert, and Holder, D.R., 1969, Work Plan II, Job 3: Life history studies: Annual report federal aid to fish restoration F-19-R-3, Georgia Department of Natural Resources, p. 74-130. 
Appendix I 


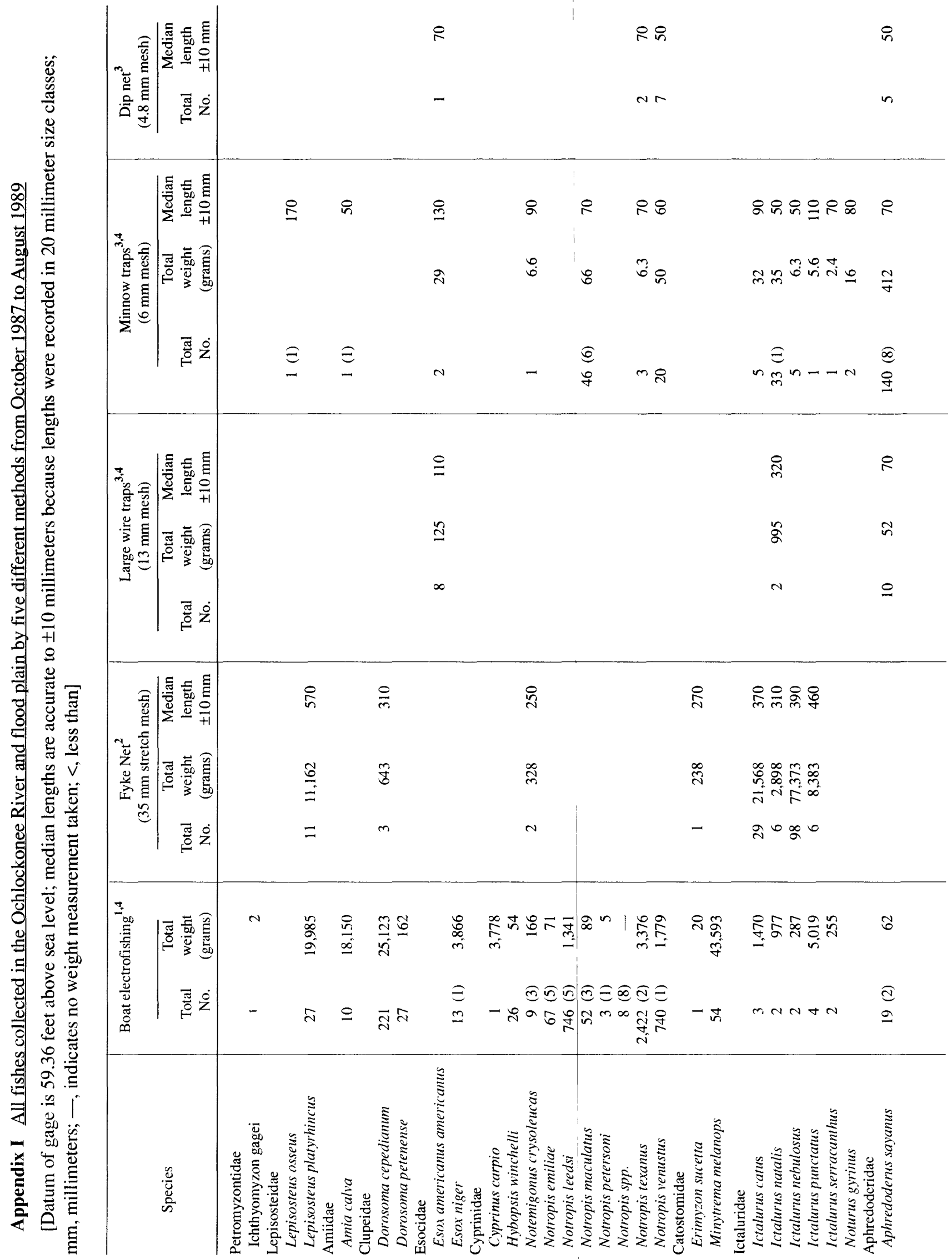




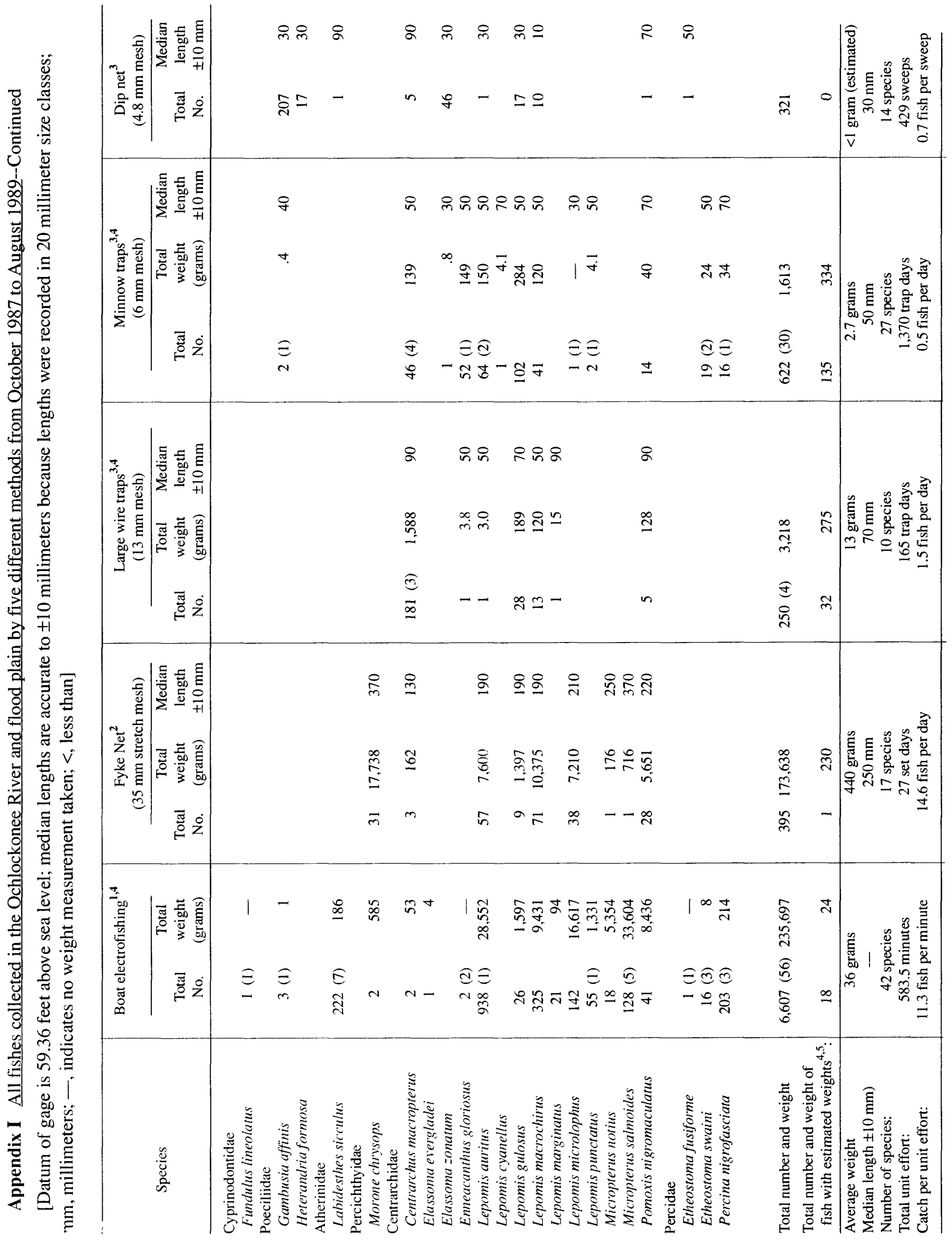




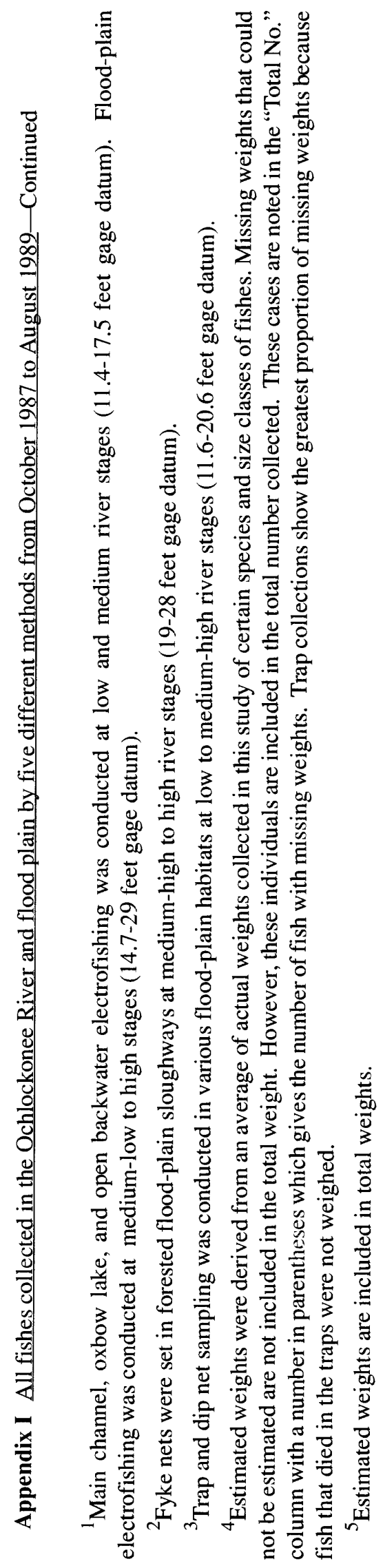


Appendix II 
Appendix II Fishes collected in the flood plain in spawning condition with sampling date, location, and hydrologic conditions [Collections were made with minnow traps, large wire traps, and dip nets]

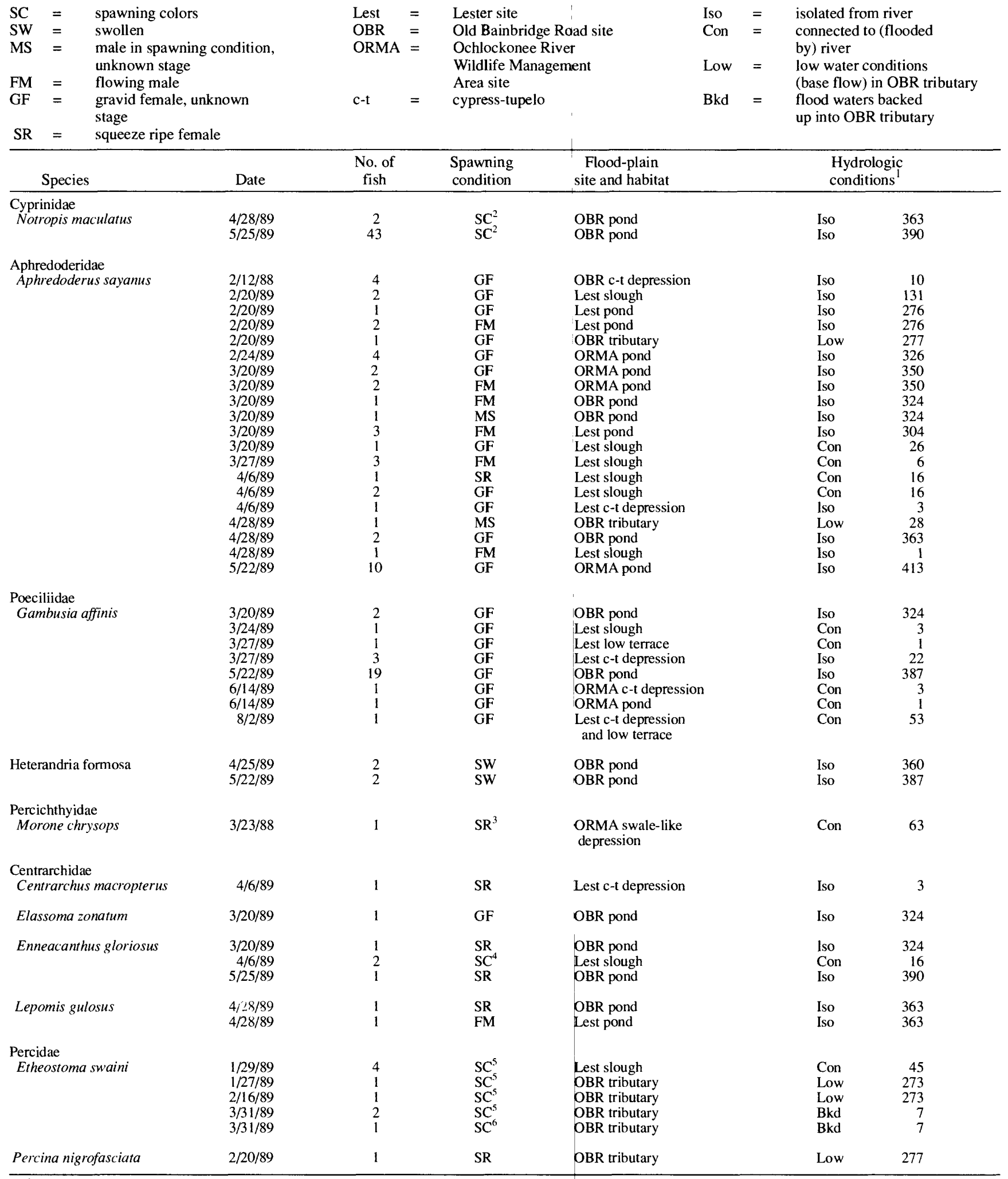

\footnotetext{
${ }^{\mathrm{I}}$ With number of consecutive days those conditions existed prior to sampling.

${ }^{2}$ Horizontal red band running length of fish and through the nose.

${ }^{3}$ Flowing female.

${ }^{4}$ Pale lime green iridescent spots.

${ }^{5}$ Orange and aqua colors.

${ }^{6}$ Orange color only.
} 
Appendix III 
[Although fishes were not aged, the fishes listed here are young-of-the-year according to the growth rates described in Carlander (1969, 1977) and Laerm and Freeman (1986). Collections were made with minnow traps, dip net, and electrofishing. One or two hundred young-of-the-year bullhead (Ictalurus sp.) 20 to 30 millimeters in length were observed but not collected on August 19, 1988, in OBR pond which had been continuously isolated from the river for 109 days. They were closely guarded by two adults approximately 300 to 350 millimeters in length; <, less than]

$\begin{array}{lll}\text { Lest } & =\text { Lester site } \\ \text { OBR } & =\text { Old Bainbridge Road site } \\ \text { ORMA } & =\text { Ochlockonee River Wildlife Management Area site } \\ \text { c-t } & =\text { cypress-tupelo } \\ \text { Iso } & =\text { isolated from river } \\ \text { Con } & =\text { connected to (flooded by) river }\end{array}$

\begin{tabular}{|c|c|c|c|c|c|}
\hline Species & Date & $\begin{array}{l}\text { No. of } \\
\text { fish }\end{array}$ & $\begin{array}{c}\text { Size class } \\
\text { (millimeters) }\end{array}$ & $\begin{array}{l}\text { Flood-plain } \\
\text { site and habitat }\end{array}$ & $\begin{array}{l}\text { Hydrologic } \\
\text { conditions } 1\end{array}$ \\
\hline
\end{tabular}

\section{Amiidae}

Amia calva

$5 / 3 / 89$

1

40-60

ORMA c-t depression

Con

11

Ictaluridae

Ictalurus natalis

rctares

Ictalurus nebulosus

$\begin{array}{lrl}8 / 16 / 89 & 15 & 20-40 \\ 8 / 16 / 89 & 1 & 20-40 \\ 8 / 16 / 89 & 15 & 40-60 \\ 8 / 16 / 89 & 1 & 60-80 \\ 8 / 16 / 89 & 1 & 60-80 \\ 6 / 19 / 89 & 1 & 40-60 \\ 8 / 16 / 89 & 2 & 20-40 \\ 8 / 16 / 89 & 2 & 40-60\end{array}$

Aphredoderidae

Aphredoderus sayanus

$6 / 19 / 89$

1

Poeciliidae

Gambusia affinis ${ }^{2}$

$5 / 3 / 88$

$5 / 19 / 89$

$5 / 22 / 89$

$6 / 14 / 89$

$8 / 16 / 89$

$8 / 16 / 89$

Atherinidae

Labidesthes sicculus

$$
7 / 27 / 89
$$

$8 / 2 / 89$

$\begin{array}{ll}2 & <20 \\ 3 & <20 \\ 1 & <20 \\ 4 & <20 \\ 1 & <20 \\ 2 & <20\end{array}$

\section{Centrarchidae}

$\begin{array}{llll}\text { Centrarchus macropterus } & 6 / 19 / 89 & 1 & 20-40 \\ & 8 / 16 / 89 & 1 & 20-40 \\ & 8 / 16 / 89 & 2 & 20-40 \\ \text { Micropterus salmoides } & 7 / 27 / 89 & 1 & 20-40 \\ & 7 / 27 / 89 & 1 & 40-60 \\ & 8 / 2 / 89 & 1 & 40-60\end{array}$

Pomoxis nigromaculatus $\quad$ 8/16/89
OBR pond

ORMA pond

OBR pond

ORMA pond

ORMA c-t depression

ORMA pond

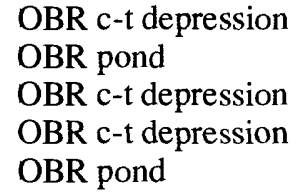

OBR c-t depression

OBR c-t depression

OBR c-t depression

Con

Iso

Iso

Iso

Iso

Iso

Con

Iso

Iso

$\begin{array}{lr}\text { Iso } & 2 \\ \text { Iso } & 410 \\ \text { Iso } & 387 \\ \text { Con } & 1 \\ \text { Iso } & 5 \\ \text { Iso } & 13\end{array}$

OBR c-t depression

Con

12

and low terrace

Lest c-t depression

Con

53

11

11

11

11

11
$20-40$

$20-40$

$20-40$

OBR c-t depression

and low terrace

OBR c-t depression

OBR c-t depression

OBR pond

$\begin{array}{lr}\text { Con } & 7 \\ \text { Iso } & 11 \\ \text { Iso } & 11\end{array}$

ORMA c-t depression

Con

$$
11
$$

and low terrace

OBR c-t depression

Con

and low terrace

Lest c-t depression

Con

12

and low terrace

40-60

OBR c-t depression

Iso

\footnotetext{
'With number of consecutive days those conditions existed prior to sampling.

${ }^{2}$ Virtually all Gambusia affinis are in their first year because individuals of this species seldom live longer than a year; however, only individuals less than 20 millimeters (which are young juveniles or small males) are listed here.
} 